\title{
Coastal Evolution, Geomorphic Processes and Sedimentary Records in the Anthropocene
}

\author{
Christopher A. Gomez ${ }^{1,2,}$, Deirdre E. Hart ${ }^{3}$, Patrick Wassmer ${ }^{4}$, Imai Kenta ${ }^{1}$, Hiroki Matsui ${ }^{1}$, \\ Mariko Shimizu ${ }^{1}$ \\ ${ }^{1}$ Kobe University, Graduate School of Maritime Sciences, VoRAS Laboratory, Kobe City, Japan \\ ${ }^{2}$ Universitas Gadjah Mada, Faculty of Geography, Yogyakarta, Indonesia \\ ${ }^{3}$ University of Canterbury, College of Sciences, Dept. of Geography, Christchurch, New Zealand \\ ${ }^{4}$ Sorbonne University Laboratory LGP \& Strasbourg University, Faculty of Environment and \\ Planning, Strasbourg, France. \\ *) Corresponding Author (e-mail: christophergomez@bear.kobe-u.ac.jp)
}

Received: 13 January 2019 / Accepted: 10 April 2019 / Published: 1 August 2019

\begin{abstract}
The question of whether or not we agree with the term Anthropocene becomes inconsequential when examining coastal environments. With few exceptions, anthropogenic encroachment on, and reshaping of, the global coastal zone is evident from space via multiple spectral views. Humans have become one of the dominant agents of coastal system change during the latest part of their relatively short existence, and nowhere is the humanization of coastal landscapes more evident than on islands. Using three island nations characterized by different stages and styles of coastal development - New Zealand, Japan, and Indonesia - we investigate the role of anthropogenic activity in coastal evolution, geomorphology and sediment records. Using field investigations, Geographical Information System (GIS) analyses, and mathematical and conceptual models, we reveals how anthropogenic activity influences processes at multiple time and space scales, with enduring effects. Our first anthropogenic impact investigation focusses on the potential effects of sea level rise (SLR) due to anthropogenic climate change. Using the earthquake-induced land-subsidence experienced in Christchurch, New Zealand, as a relative SLR example ('Laboratory Christchurch'), evidence shows that coastal settlements are likely to be impacted not only at the shore but further inland via coast-connected waterways, where drainage is impeded due to an increase in the base level of that is the sea. Relative SLR makes it more difficult to evacuate water from subaerial and subsurface hydro-systems, and simulations show that future SLR is also likely to temporarily reduce some river-mouth sediment discharges, creating the potential for accelerated erosion in river-coast interface environments. In addition to flow-on effects from waterways, coastlines themselves have been highly affected by human activity over recent decades to centuries. In Tokyo, the shoreline has undergone artificial pro-gradation, in places by more than $2 \mathrm{~km}$, where concrete has supplanted mudflats, often at elevations above the hinterland of reclaimed areas. In addition to changes in Tokyo's unconsolidated shores, consolidated coastal cliffs have been modified with the removal of natural talus buffers, again increasing the potential for erosion acceleration. Finally, in our third example, studies of the 2004 Indian Ocean tsunami and the 2011 Tohoku tsunami show that anthropogenic activities and structures play an important role in controlling the erosion and deposition of sediments during extreme events. A chronology of tsunami deposits from the Tohoku coast shows that sedimentary records from tsunami events have become thinner in recent centuries, independent of the incident tsunami wave hydrodynamics, and in relation to increasing levels of coastal plain, shoreline and nearshore development. In light of these multi-scale and multiprocess effects, we argue that the Anthropocene is clearly distinguishable from the Holocene in coastal environments due to the significantly stronger signatures of human influence that characterise the former time period.
\end{abstract}

Keywords: anthropocene, climate change, coastal environment, maritime sciences. 
Abstrak. Pertanyaan apakah kita setuju dengan istilah Anthropocene menjadi tidak penting ketika melakukan studi di lingkungan pesisir. Dengan sedikit pengecualian, perambahan antropogenik, dan pembentukan kembali, pada zona pesisir global terbukti dari ruang angkasa melalui berbagai tampilan spektral. Manusia telah menjadi salah satu agen dominan perubahan sistem pesisir selama bagian terakhir dari keberadaannya yang relatif singkat, dan tidak ada tempat untuk memanusiakan pemandangan pantai yang lebih jelas daripada di pulau-pulau. Dengan menggunakan tiga negara pulau yang ditandai oleh berbagai tahap dan gaya pengembangan pesisir - Selandia Baru, Jepang, dan Indonesia - kami meneliti peran aktivitas antropogenik dalam evolusi pesisir, geomorfologi, dan catatan sedimen. Menggunakan investigasi lapangan, analisis Sistem Informasi Geografis (SIG), dan model matematika dan konseptual, kami mengungkapkan bagaimana aktivitas antropogenik memengaruhi proses pada skala waktu dan ruang yang beragam, dengan efek yang bertahan lama. Investigasi dampak antropogenik pertama kami berfokus pada efek potensial kenaikan permukaan laut (SLR) karena perubahan iklim antropogenik. Dengan menggunakan penurunan tanah yang disebabkan oleh gempa yang dialami di Christchurch, Selandia Baru, sebagai contoh SLR relatif ('Laboratorium Christchurch'), bukti menunjukkan bahwa pemukiman pesisir kemungkinan akan terkena dampak tidak hanya di pantai tetapi lebih jauh ke daratan melalui saluran air yang terhubung dengan pantai, di mana drainase terhambat karena peningkatan tingkat dasar yaitu laut. SLR relatif membuat lebih sulit untuk mengevakuasi air dari sistem hidro bawah permukaan dan bawah permukaan, dan simulasi menunjukkan bahwa SLR di masa mendatang juga cenderung untuk sementara waktu mengurangi beberapa buangan sedimen aliran sungai, menciptakan potensi erosi yang dipercepat di lingkungan antarmuka sungai-pantai. Selain efek mengalir dari saluran air, garis pantai sendiri telah sangat dipengaruhi oleh aktivitas manusia selama beberapa dekade terakhir hingga berabad-abad. Di Tokyo, garis pantai telah mengalami progradasi buatan, di tempattempat lebih dari $2 \mathrm{~km}$, di mana beton telah menggantikan lumpur, sering di ketinggian di atas pedalaman daerah reklamasi. Selain perubahan di pantai Tokyo yang tidak terkonsolidasi, tebing pantai yang terkonsolidasi telah dimodifikasi dengan menghilangkan buffer talus alami, yang lagilagi meningkatkan potensi percepatan erosi. Akhirnya, dalam contoh ketiga kami, studi tentang tsunami Samudra Hindia 2004 dan tsunami Tohoku 2011 menunjukkan bahwa aktivitas dan struktur antropogenik memainkan peran penting dalam mengendalikan erosi dan deposisi sedimen selama peristiwa ekstrem. Sebuah kronologi endapan tsunami dari pantai Tohoku menunjukkan bahwa catatan sedimen dari peristiwa tsunami telah menjadi lebih tipis dalam beberapa abad terakhir, terlepas dari insiden hidrodinamika gelombang tsunami, dan dalam kaitannya dengan peningkatan level dataran pantai, garis pantai dan pengembangan dekat pantai. Mengingat efek multi-skala dan multi-proses ini, kami berpendapat bahwa Anthropocene jelas dapat dibedakan dari Holocene di lingkungan pesisir karena tanda tangan yang lebih kuat dari pengaruh manusia yang menjadi ciri periode waktu sebelumnya.

Kata kunci: anthropocene, perubahan iklim, lingkungan pesisir, ilmu maritim.

\section{Introduction}

In 2016 the term 'Anthropocene' inspired vigorous debate regarding the question of its existence on the Geological Society of America forum page(http://community.geosociety.org/ please note that a login is required). One group of geologists argued that the Anthropocene could not match the traditional requirement to be recognized as a new epoch, while others insisted that it was a valid term to recognize the now unprecedented impacts that humans have had on their environment. Although debates still rages (Trischler, 2016), in August 2016 the International Commission on Stratigraphy Working Group on the Anthropocene voted to formally designate the epoch Anthropocene and presented this recommendation to the International Geological Congress. 


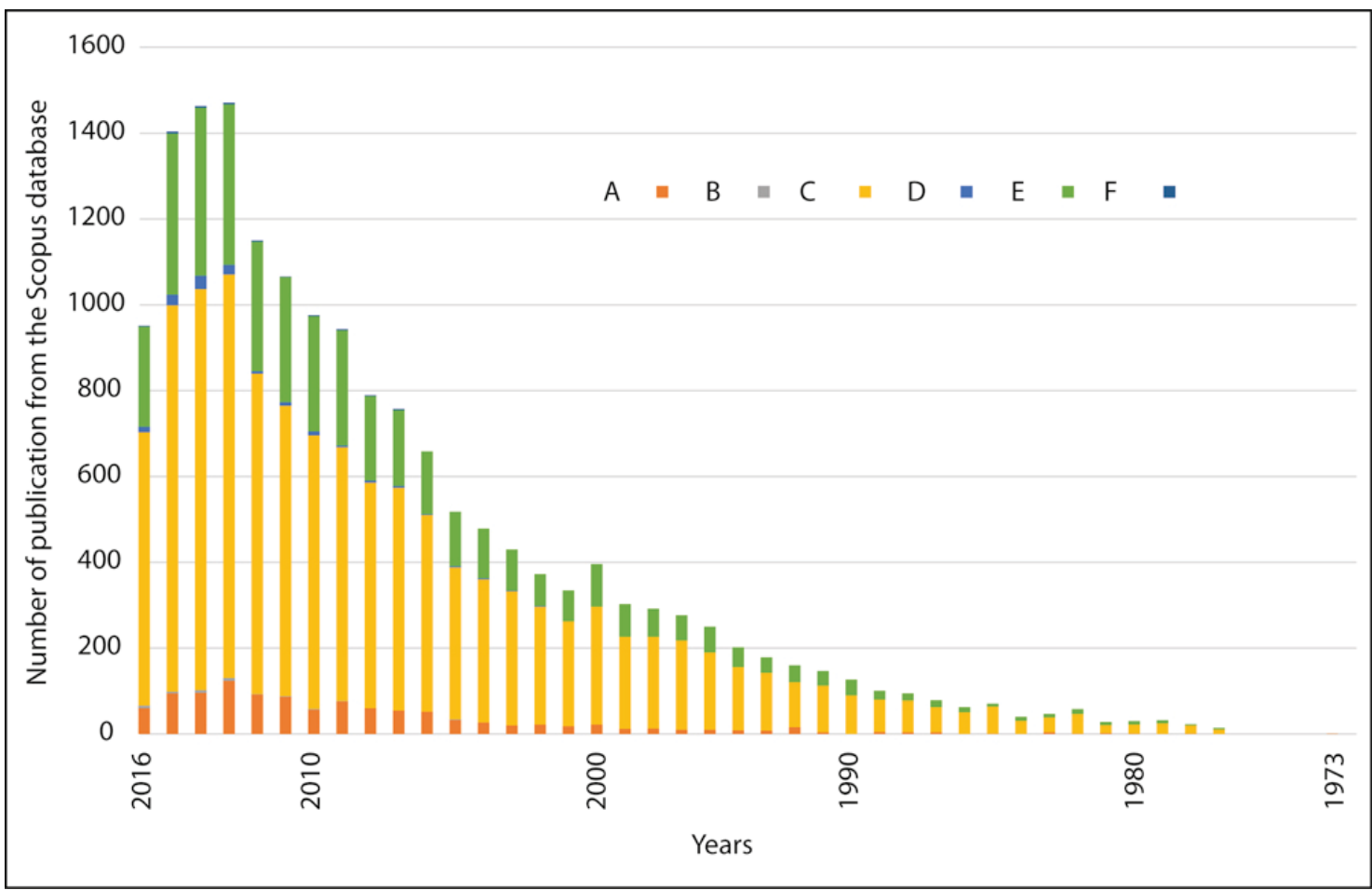

Figure 1. Number of publications on the Anthropocene, anthropogenic, geomorphology, sediments and the coast since 1973. (A) Anthropogenic AND Geomorphology; (B) Anthropocene AND Geomorphology; (C) Anthropogenic AND Sediment; (D) Anthropocene AND Sediment; (E) Anthropogenic AND Coast; (F) Anthropocene AND Coast.

While debate has reached new levels, the concept of Anthropocene is not new, having origins in the $19^{\text {th }}$ century when Italian geologist Antonio Stoppani (Stoppani, 1873) proposed the 'Anthropozoic' as a new geologic era ending the Cenozoic, a proposal that was far more extreme than the change of epoch argued for by recent pro-Anthropocene scientists (Crutzen and Stoermer, 2000). Rull (2016) captured the different standpoints on the question of the reality of the Anthropocene and the difficulty of projecting oneself into the future to know whether or not humans will leave a significant signature in the sedimentary record.

Currently, coastal and sediment scientists tend to shy away from using the term Anthropocene, as evidenced in their literature. So far in 2016 according to Scopus data for example (Figure 1), the term Anthropocene has been used only 13 times in sediment related publications versus the term anthropogenic, which has been used 637 times. Similarly, 60 papers use anthropogenic geomorphology compared to only
6 which use Anthropocene and geomorphology. In 2016 coastal literature cited in Scopus, only one publication has used the term Anthropocene while 234 such publications have used the term anthropogenic.

In terms of literature usage, the term Anthropocene is more recent than anthropogenic. An English language publication on anthropogenic effects on sediment was published as early as 1972 (Kowalinski et al., 1972 - note that this does not mean it is the first publication - we are aware that numerous studies and ideas have been developed in Japan, for instance, long before they were considered in English language works but did not make it to the mainstream scientific literature). However, it is not until 2011 that the concept of the Anthropocene emerges in publications focussed on sediments and geomorphology (Figure 1).

Geomorphology has traditionally been associated with abiotic forcings such as tectonism or hydrology, although recently the role of biota in shaping landscapes has been the focus of specialized fields such as 
zoogeomorphology (Butler, 1995; Hall and Lamont, 2003; Butler and Sawyer, 2012), ecogeomorphology (e.g. van Maanen et al., 2015) and ecosedimentology (Hart and Kench 2007; Woodroffe et al., 2007), focussing on environments as diverse as mountains, estuaries and tropical reefs. Anthropogenic activity has been largely treated as external to Earth system dynamics and separate from biotic agents. This is despite the ever increasing effects of humans, including as a geologic agent (Wilkinson, 2005; Tarolli and Sofia, 2016), as 'natural' process influence (Wolf et al., 2014), and an interactive agent that is not 'in control of' Earth surface processes (Wohl, 2013).

Although the present contribution does not aim to engage in the debate surrounding the term Anthropocene, we see it as undeniable that $20^{\text {th }}$ and $21^{\text {st }}$ century nuclear tests, accidents and wars have left a measureable amount of radioactive material in recent stratigraphy (Waters et al., 2016). In the present contribution, we use the term Anthropocene to investigate the role that human activity and settlements have had on Earth surface processes and deposits at the coast.

With few exceptions, anthropogenic effects on the global coastal zone are evident from space via multiple spectral views, including in the real-colour, infrared, and microwave spectrums (Ozesmi and Bauer, 2002; Parkinson and DiGirolamo, 2016; Qu et al., 2012). Images of NASA's 'black marble' demonstrate that our intense level of development of, and encroachment on, coastal environments is even apparent at night. We humans have become one of the predominant agents of coastal system change during the latest part of our relatively short existence (Lotze et al., 2006) and nowhere is the 'humanization' of coasts more evident than on islands (Tsai and Clark, 2003).

The geomorphic influence of humans extends from the mountains to the sea, where ultimately human activity can literally shift coastlines. Rodriguez-Ramirez et al. (2008), for example, have forecasted that a combination of climate-change induced sea-level rise, human modification of catchment flows, sediment delivery and deposition patterns, and shoreline hardening will lead to 10 to 15 $\mathrm{m}$ of coastal retreat in southwest Spain. Similar observations have been reported much earlier for other locations. Hudson (1980) explained how coastal dredging, footpaths and heavy vehicle use on sandy coasts led to rapid erosion and changes in deposition patterns. Others have argued that estuaries have profoundly changed during the Anthropocene, particularly under the influence of river basin modification, including sediment starvation due to dredging for fluvial navigation (Benedet et al., 2008; Wei et al., 2016). Reductions in sediment delivery to the coastal zone due to impoundment and river 'training' works have been observed in large rivers across different climatic zones (Syvitzki and Saito, 2007), including in the Yangtze (Wei et al., 2016), the Mississippi (Blum and Roberts, 2009), and the Nile (Stanley and Warne, 1993). Human influence on coastal sediment delivery is not unidirectional, however, with advances in green engineering proving useful in counteracting some sediment starvation effects (Wang et al., 2013).

It, therefore, appears that the literature is already rich in research on the impacts of anthropogenic activities on coastal streams, basins and coastlines, with issues reported along the coast of most coastal nations (see Masselink and Gehrels, 2014 for discussions on human influences in specific types of coastal environment). Amongst others, one key scientific challenge in understanding anthropogenic influences on Earth systems (Shakesby and Doerr, 2006; Walling, 2006; Knight and Harrison, 2013) that remains is the difficulty of predicting response timings in systems characterized by nonlinear, chaotic behavior (e.g. Hooke, 2007; Phillips, 2009; Houben et al., 2012; Gomez and Soltanzadeh, 2012). Questions of complexity have been increasingly examined using stochastic models and systems, but these have offered little, so far, in elucidating the timing of nonlinear processes. 
This paper focuses on the role of human activity in shaping the coast, both in terms of everyday coastal states (including functioning that is recorded geomorphically over the long term); and in terms of high-energy events within coastal zones. The choice of these two themes is essential to understanding coastal evolution, geomorphic processes and the sedimentary record of the Anthropocene. This is because, even though anthropogenic activity influences everyday functioning in coastal systems, in the past one might have argued that its influence became more minor in the face of extreme events. We argue that this is no longer the case, with anthropogenic activity influencing both the every-day, relatively low-energy processes as well as low-frequency higher-energy events. The aim of this paper is to show that the influence of anthropogenic activity is pervasive across all scales of coastal zone processes and, thus, we aim to collate example evidence in support of the idea of the present existence of a properly Anthropocene coastal system.

\section{Methodology}

This contribution combines field data gathered over the last decade from New Zealand, Japan, and Indonesia; Geographical Information System (GIS) and morphometric analyses of topography and built structures; conceptual process models; and a simple one dimensional diffusion model to explain the role of present and future anthropogenic activities, including future accelerated sea level rise (SRL), on sediment transport and deposition in the case study coastal environments.

\subsection{Study settings in New Zealand, Japan, and Indonesia}

The authors have worked on coastal projects in New Zealand, Japan, and Indonesia for over a decade, and although the role of anthropogenic activity was never the initial centre of attention, datasets arising from this work have repeatedly revealed the presence of human influences on geomorphology and sediment records.
In New Zealand, the authors have researched the direct and cascading effects of the February 2011 earthquake sequence, which induced extensive liquefaction, river bank mass movement and widespread subsidence of between $50 \mathrm{~cm}$ and $100 \mathrm{~cm}$ across large tracts of the city (Allen et al., 2014; Davis et al., 2015). Due to the overwhelming interconnectedness of these earthquake damage patterns and coastal environments, past and present (Hart and Gomez, 2013; Hart et al., 2015), Hart coined the term 'coastal quake' to explain how coastal or delta city settlements interact with seismic events to produce disproportionate geomorphic and human environment change. Due to the extensive subsidence, the base level of Christchurch is now lower relative to the adjacent sea, meaning that the city has effective experienced relative sea level rise (SLR) at its coast and in relation to much of the inland waterways. The city is, thus, now an excellent laboratory in which to study the impact of SLR (e.g. Hart, 2014), and from which to forecast the likely effects of anthropogenic climate change on geomorphic and sedimentation processes.

In Japan, the authors have worked on deposits from the 2011 Tohoku tsunami along the bays near Minami-Sanriku and used a geoslicer in Agawa pond (UTM 54N 504982, 4238027), revealing extensive anthropogenic debris. The authors investigated the influence of the last half century of human development on this coastal plain environment on the generation of tsunami deposits. Helicopter video footage of the tsunami from the Japanese national television channel NHK was also analysed to understand how built infrastructure affected and interacted with the inland progression of the tsunami.

In the province of Banda Aceh, northern Sumatra Island, Indonesia - lampuuk area: UTM46N 748390, 602950 - 746800, 602950 (Kain et al., 2014), work focussed on deposits laid down during the 2004 Indian Ocean tsunami to try understand the wave and inundation dynamics (Wassmer and Gomez, 2011). Since this coast was densely populated, 
these deposits also revealed anthropogenic influences. Further, aerial photographs collected by Wassmer, as part of a United Nations (UN) post-disaster reconnaissance, in the tsunami aftermath helped to explain the role of built infrastructure in controlling patterns of tsunami inundation and impact.

Collectively these three case studies provide data that elucidates selected (i) effects of anthropogenic activity on sediment systems; (ii) interactions between anthropogenic activity, built infrastructure, and earth surface and sedimentation processes; and (iii) how the anthropogenic climate change is likely to affect coastal settlements worldwide over the coming decades and centuries.

\subsection{GIS mapping and analysis}

Like the Great Wall of China, evidence of anthropogenic activity at the coast can be seen from space in the form of sea walls separating land and sea. Accordingly, evidence of built infrastructure and changes in coastal environments brought about by anthropogenic activity were collected using satellite imagery of the land-surface as well as from GIS data that had been either constructed from the satellite imagery or from existing databases. For Japan, the Tokyo University Centre for Spatial Information Sciences (CSIS) provided the research team with shapefiles of the Tokyo area while the Geographical Information Authority of Japan (GSI) provided data for the Tohoku area, with additional GIS, image and sediment data collected in the field by the authors. The field data are concentrated on locally dug sediment pits along the waterways and in the Sendai plain and the bays to the North. Particular attention was given to Agawa-pond as the sedimentary record was collected for further research (Wassmer et al. on Agawapond in preparation). In Indonesia, GIS, sediment and image data were also collected in the field by the authors, and, finally, in New Zealand the data was collected through a research partnership between the University of Canterbury and the Canterbury
Regional Council Environment Canterbury (Canterbury Geotechnical Database, 2012a, $2012 b, 2014)$. The various datasets were then adapted and normalized to generate information through geospatial analyses performed using ESRI's ArcGIS software and the open-source software QGIS: calculations made were on the whole simple, with mostly distances and surface areas calculated.

\subsection{Conceptual and numerical models}

The present article comprises a synthesis and reanalysis of several years of observations and measurements from different projects. Accordingly we have created several conceptual models to summarise the different case studies. Also, the case study of the potential influence of human-induced SLR on coastal river systems was investigated by applying a diffusion numerical model.

Sediment transport in rivers into the sea is best represented by the balance between sediments being transported by the river and then eroded or deposited in the coastal zone. The river component of sediment transport has been examined using different numerical methods, including the relation between shear stress $(\tau)$ and discharge (Q): Pitlick and Wilcock (2001), for example, calculated the dimensionless shear stress at the bed as $0.003 \mathrm{Q}^{0.37}$. The transport or settling of sediments can be represented as a function of discharge, which is river cross-section multiplied by velocity, provided that the crosssections are relatively constant. The velocity is determined by the gradient between the base and start levels. Reduced to a dimensionless relation, the river gradient can be transformed into a transfer gradient, which we modelled using the differential diffusion equation. This is the most extensively used equation for sediment transport in river systems and is applicable when transport is proportional to the slope, and mass is conserved. The discharge of sediment (Qs) is proportional to changes in slope $(S)$ (in the present case we assume slope is river slope), where $d$ is the 
diffusivity gradient, and $x$ is a coordinate in space, then (Equation 1):

$$
Q_{s=-d} \frac{\partial S}{\partial x}
$$

From Equation 1 the one-dimensional diffusion equation can be written (Equation 2):

$$
\frac{\partial S}{\partial t}=d \frac{\partial^{2} S}{\partial x^{2}}
$$

and $t$ is time. We solved the above diffusion equation in Matlab, using a finite difference method with an implicit numerical scheme first order upwind in time, and second order central difference in space. Using Dirichlet boundary conditions upstream and downstream, as well as variation in the river sediments, we conducted a series of simulations that helped elucidate the influence of changes in the river base level on a sediment transfer system, a coastal plain stream, reaching a coastal water-body, the Pacific Ocean.

\section{Results and Discussion}

\subsection{Anthropogenic SLR at the intersection} between coastal processes and river processes

Accelerated SLR is perhaps the most topical of all future predicted effects of anthropogenic climate change, albeit that majority literature on this topic focusses at global to regional scales rather than on detailed local investigations. In the aftermath of the 2010 to 2011 Canterbury Earthquake Sequence (CES), the land elevations of large tracts of the city of in Christchurch were left subsided by 0.5 to $1.0 \mathrm{~m}$, particularly in and along the two major waterways, the Ōtākaro Avon River and the ŌpāwahoHeathcoteRiver. Since the land levels had subsided around this river, while the ocean levels remained unchanged, this effectively meant that large areas of the coastal plain that the city is built on experienced relative SLR (Figure 2). This relative SLR was equivalent in magnitude to the absolute SLR that has been predicted for this region over the $21^{\text {st }}$ Century (Hannah and Bell, 2012) but it occurred within a few months, as a result of seismic processes and a cascade of coastal/ river plain interactions, in particular liquefaction processes (Hart and Gomez, 2013; Hart et al., 2015).

In March 2014, Christchurch experienced an extreme rainfall event, which manifested on the newly- lowered ground as extreme flooding (Allen et al., 2014). The flooding was significantly enhanced by several earthquake related factors, including the partially broken state of the stormwater infrastructure, changes in the river channel cross-sections and in the level of the land adjacent to the river banks, the increased basinisation of some parts of the city, the relatively high groundwater levels (since some land surfaces had subsided substantially closer to the water table, reducing freeboard and drainage capacity), and also due to the elevation of sea levels under an atmospheric low pressure system out at sea and at the mouth of the city's main rivers in the Avon-Heathcote Estuary Ihutai. These myriad of factors combined to create a 'piling up' of water in city's the waterways (Figure 3). The HecRas simulation results with different boundary conditions, exemplifying the effects of the Anthropocene sea-level rise (present day MSL (mean sealevel), $+0.5 \mathrm{~m}$ and $+1 \mathrm{~m}$ ) show that mode flow (providing that the land-hydrology remains similar) will present the most important change near the coast, but larger discharges will impact upstream areas as well. As the water speeds up in the waterways, the flood propagates upstream the channel (one will note that the 2011 earthquake has lowered important lengths of the lateral banks in such a way that a very small variation in the base level or water intake in the system creates an important flood hazard for the city). 


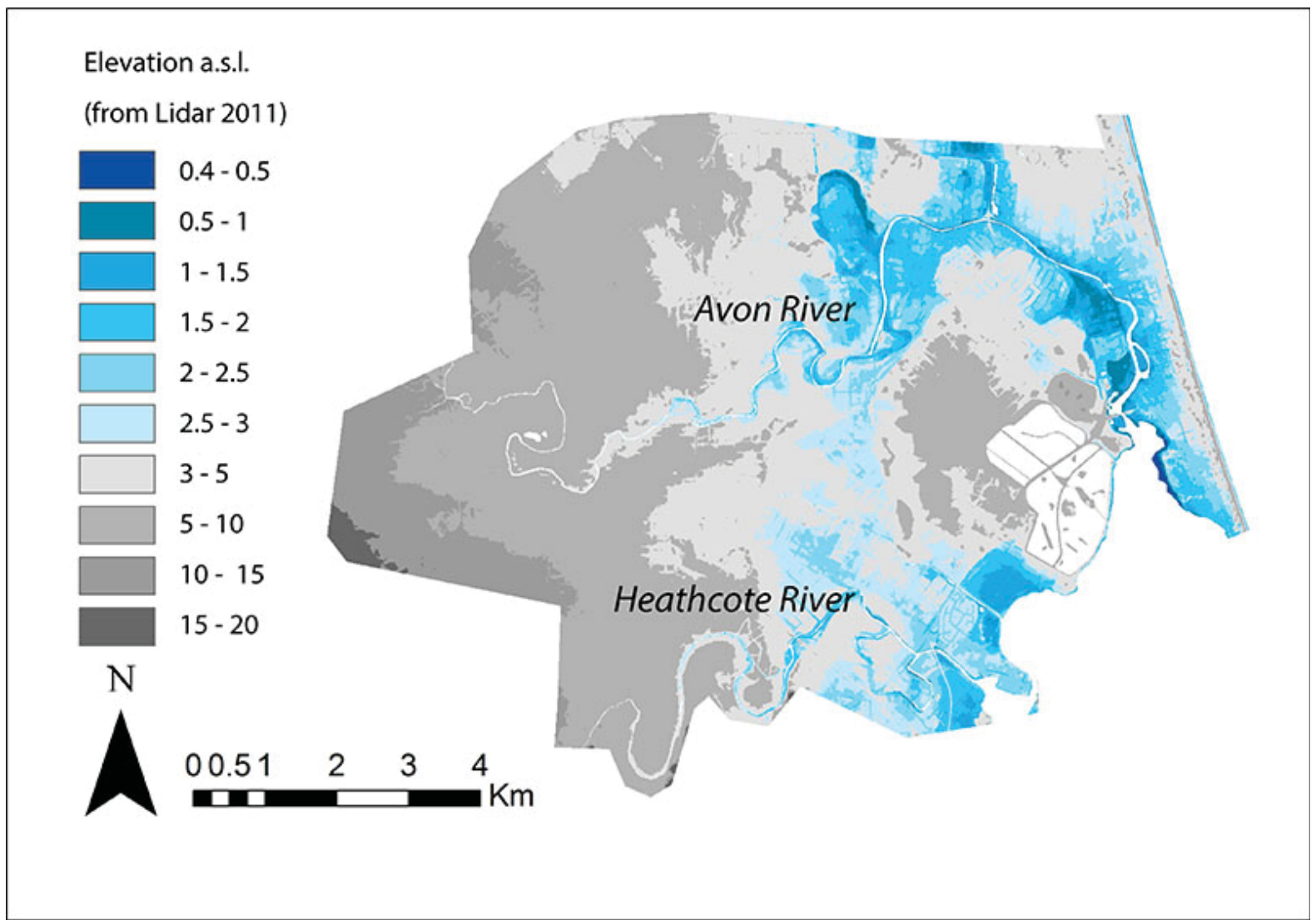

Figure 2. Elevation map of Christchurch City in the aftermath of the 2011 Canterbury Earthquake, showing the two rivers feeding into the Avon-Heathcote Estuary Ihutai (the Ōtākaro Avon River in the north, and the Ōpāwaho Heathcote River in the south), being the most impacted by the earthquake due to liquefaction and lateral spreading, bringing their level within 1 m of mean sea level.

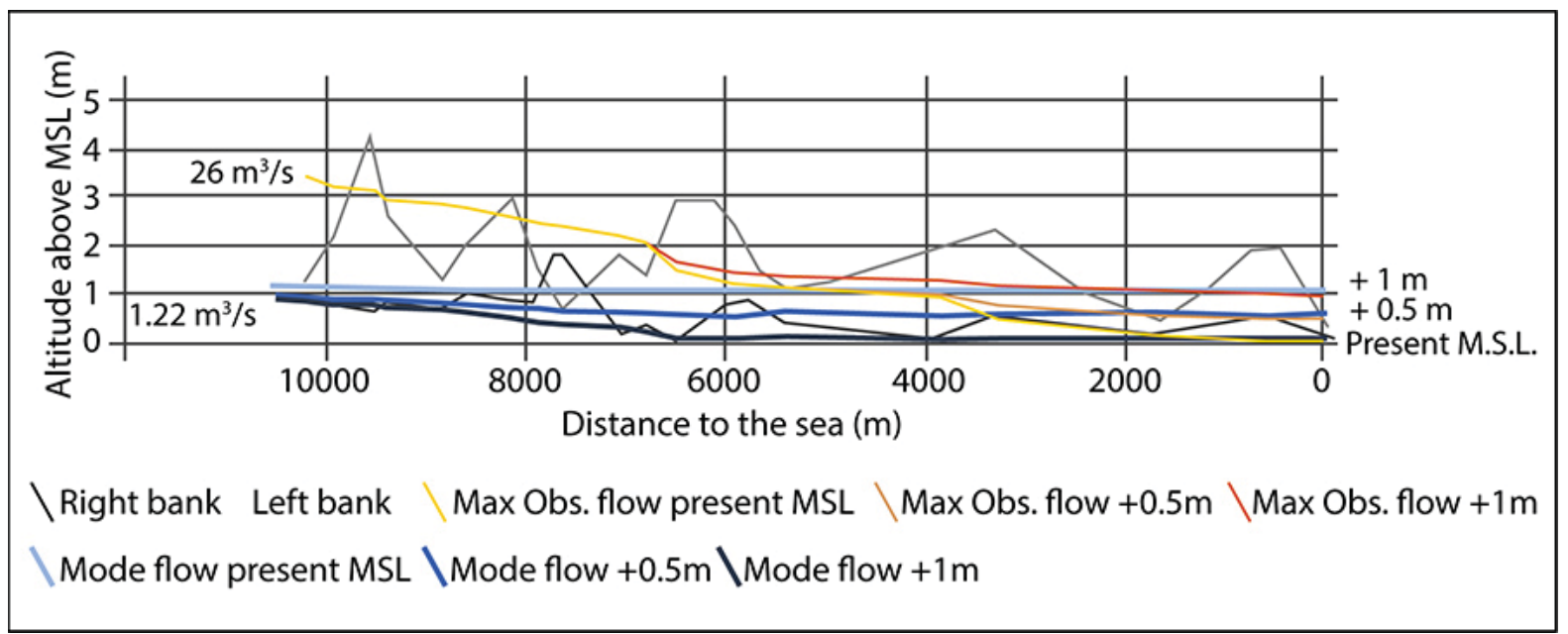

Figure 3. Hydraulic simulation of the role of anthropogenic climate change sea level rise on river stage for the mode flow and the maximum observed discharge. One will notice the rise in the upstream area from $6 \mathrm{~km}$ away from the river mouth. 


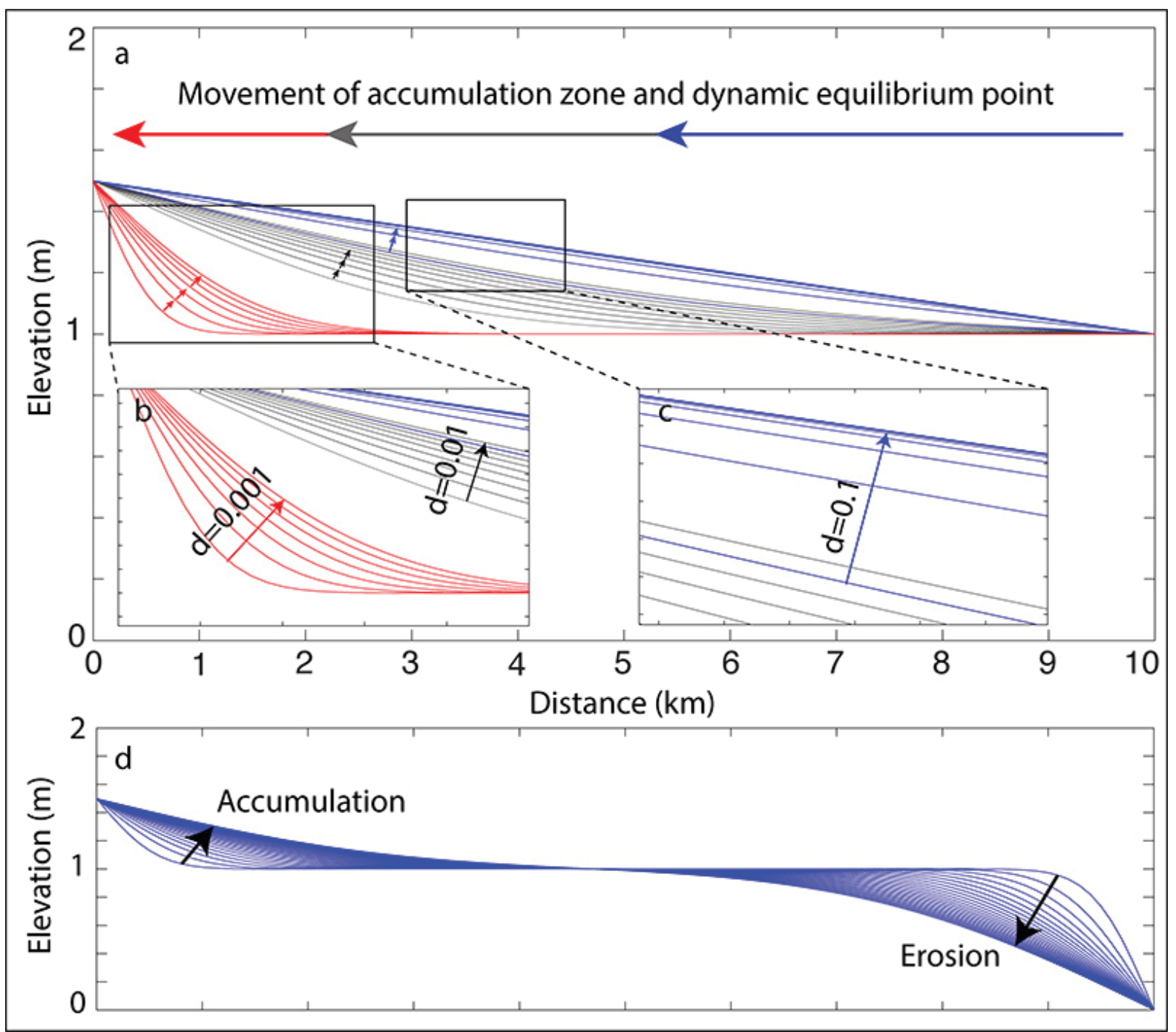

Figure 4. Simulations of longitudinal sediment diffusion in an idealized coastal stream: (a) comparison of results generated using three different stream gradients acting on (with $d$ of 0.001, 0.01 and 0.1, respectively) on sediment transfers and therefore the zones of erosion and accumulation; (b) detail of low-gradient simulations, showing slow transfers throught the stream; (c) detail of the rapid upstream spread of the equilibrium gradient of the bed; (d) simulation of the combination of a low-gradient case with sediment starvation at the river mouth, where the boundary condition is kept at 0 accumulation.

In order to better understand the boundary condition was modified to reflect processes behind the changes that we the reduction in the river's energy gradient observed occurring in the field setting of but the erosive power of coastal processes was post-earthquake Christchurch, we used a one-dimensional sediment diffusion model to simulate change in an idealised streams on the coastal plain (Figure 4). In model simulations, the SLR was input as a boundary condition, thereby modifying the overall river gradient. This resulted in rapid stream bed responses: it led to upstream sedimentation, lessening downstream sediment transfers (Figure 4 - b\&c). We found that if the downstream maintained, then regressive erosion ensued at the river mouth (Figure $4-\mathrm{d}$ ).

Although the relative SLR experienced in Christchurch between 2010 and 2011 differed in its suddenness to that which is anticipated over the next century with global climate change, this phenomenon has provided the scientific community with the opportunity to study some of the response mechanisms that might characterise both scenarios. The 
evidence reveals that coastal river systems are highly susceptible to change, perhaps even more susceptible than the coastline itself since the latter environment may have more than fluvial sediment sources. In particular, we observed in model simulations as well as during the March 2014 extreme rainfall events that, when SLR elevates the base level of water at the river mouth, flow has more difficulty evacuating the system (Figure 5). At the same time, this base level elevation was accompanied in model simulations by in-stream sediment accretion due to reduction in the river gradient. Over the short to medium term, this resulted in sediment starvation at the river mouth here the balance between littoral sediment transport and river deposition affects the outcome in the river channel (Figure 5), with additional cascading effects on the sediment budget of the adjacent coast. Together, these changes in river geomorphology and flow capacity, in turn, influence other associated surface processes such as floods.

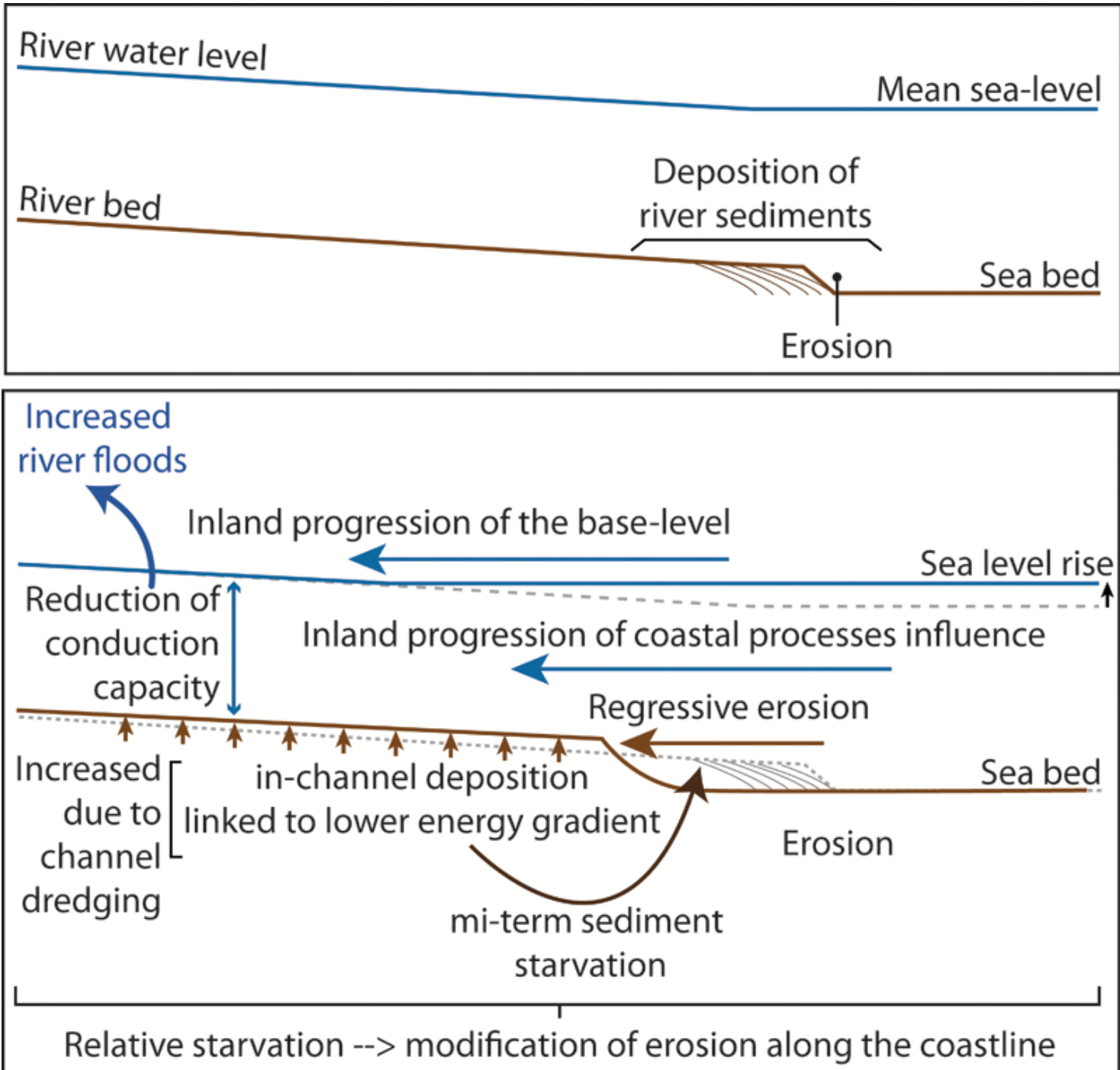

Figure 5. Conceptual framework of the interplay between sea level rise (SLR), river flow, sediment transport and flooding of the coastal plain. This conceptual model was built from the experience of Christchurch city's relative SLR, produced by land subsidence in the 2010-2011 CES. 


\subsection{Coastal processes and flux modified by anthropogenic settlements and activity}
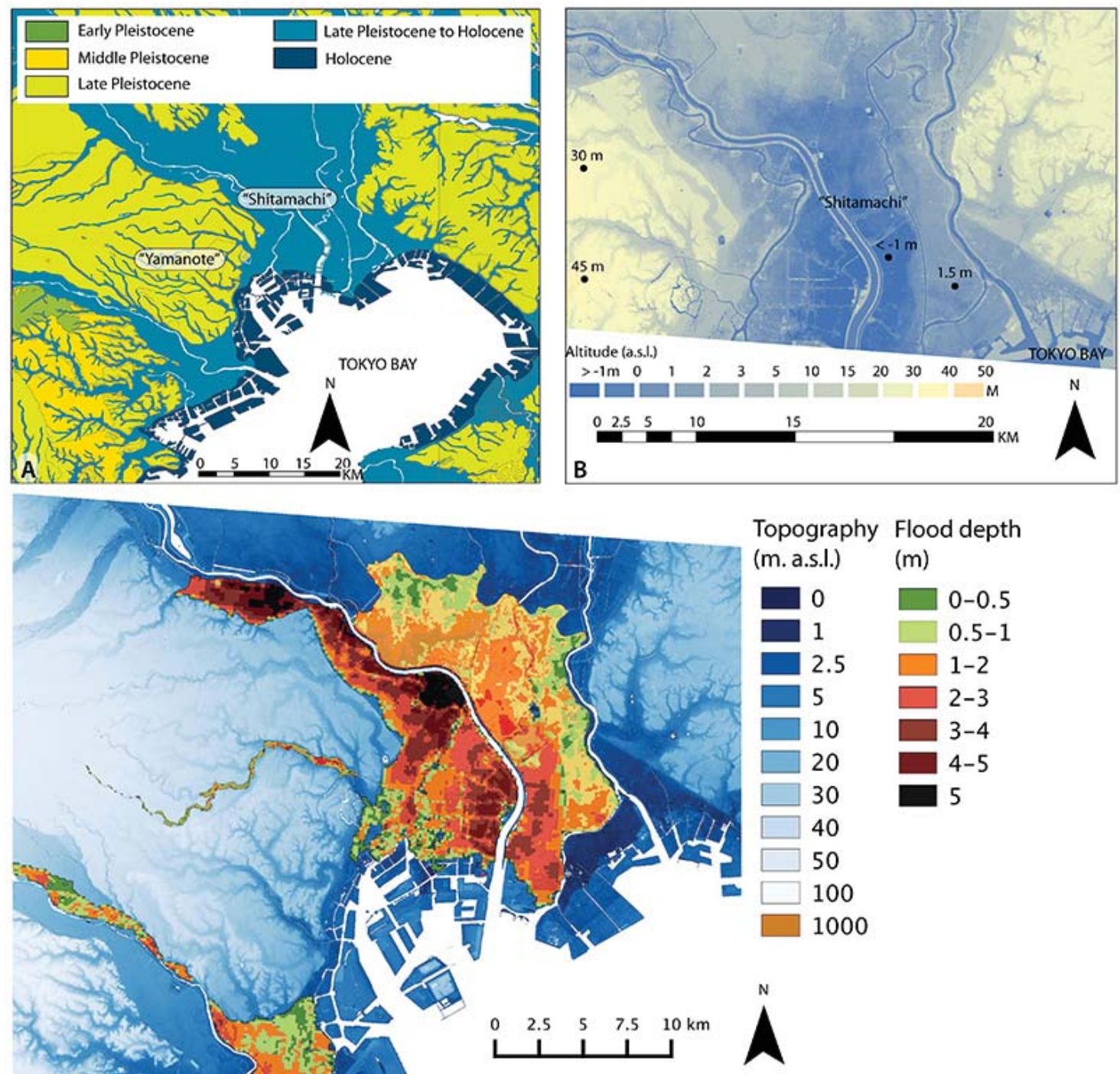

Figure 6. (A) Geologic age of Tokyo bay natural formations, and 'human-made' (Holocene dark blue) coastal features; (B) LiDAR-derived digital elevation model (DEM) of the Shitamachi area, showing how large tracts of the coastal and river plain sit lower than the 'human-made' coastal features; and (C) shows the maximum river flood depth in Tokyo, mostly attained during typhoons This emphasizes the dichotomy between newly built reclaimed land and the natural coastal plain.

Sediment transfers between terrestrial and coastal environments occur not only through river and rivermouth processes but also through a complex web of landsea interactions, including via cliff, wetland and hinterland sediment exchanges, via subaerial wreathing, mass movement and overland flow processes, and via aeolian transfers. Anthropogenic development, reclamation and other modifications of the coast have, within one human generation, produced shoreline changes equal to those that characterise geological timescales (Figure 6). Anthropogenic land reclamation has shifted Tokyo's shoreline seaward by up to 2 $\mathrm{km}$ in the east and up to $3 \mathrm{~km}$ in the west of the city. This land reclamation has tended to occur via the construction of hard shorelines and surfaces, with backfilling, and has not been accompanied by corresponding rates of nearshore accretion, so that water depth at the coastline has increased, and nearshore sediment deposits present at the coast at the start of the $20^{\text {th }}$ century have, in turn, been recovered if not 
converted into reclaimed land (Figure 7). We examined three locations in east Tokyo and found that the coastline had been artificially shifted seaward by between 1600 and 2000 . Here $540 \mathrm{~m}$ to $2000 \mathrm{~m}$ wide mudflats had also disappeared beneath the land reclamations. That is, small mudflats previously covering $0.13 \mathrm{~km}^{2}$, with surrounding tidal streams, and larger mudflats previously covering almost 7 $\mathrm{km}^{2}$, had all disappeared.
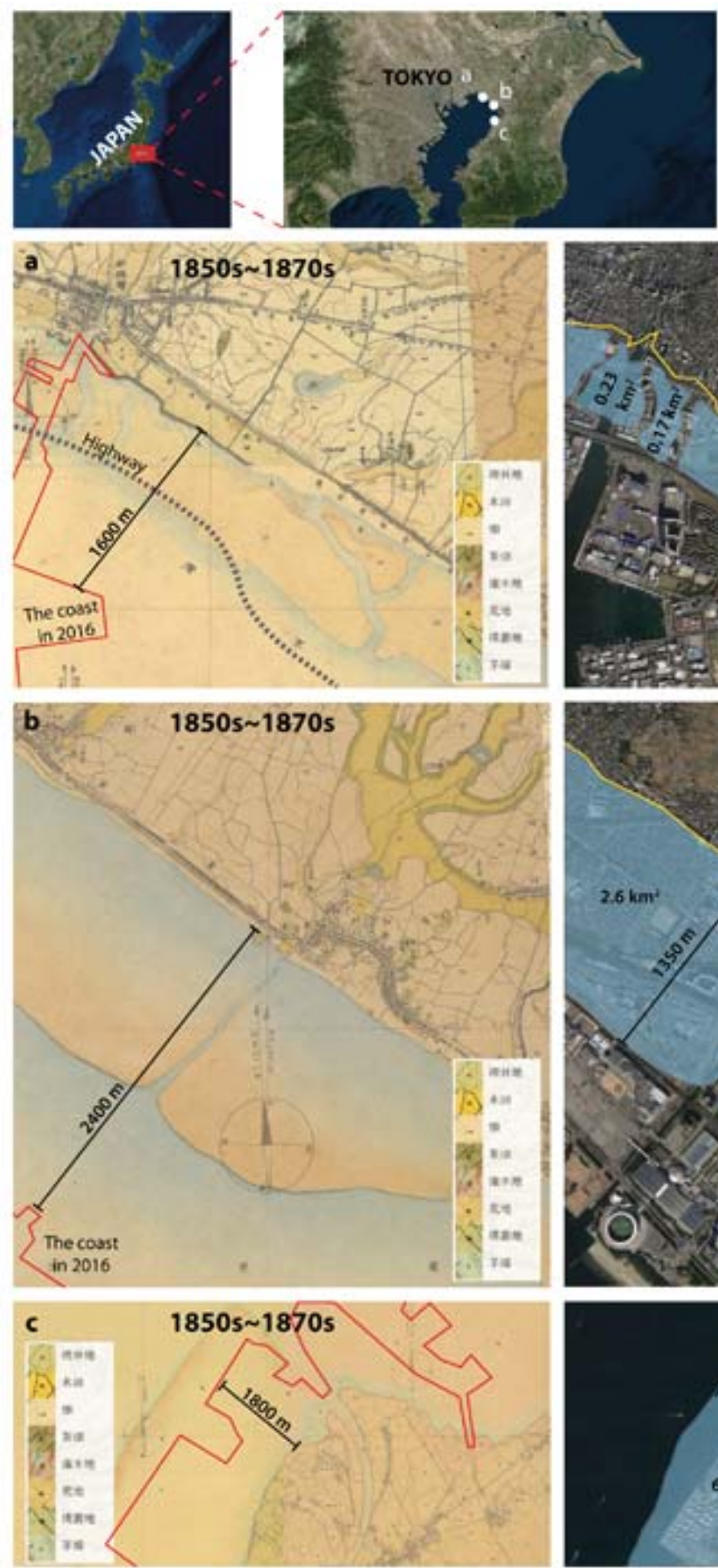
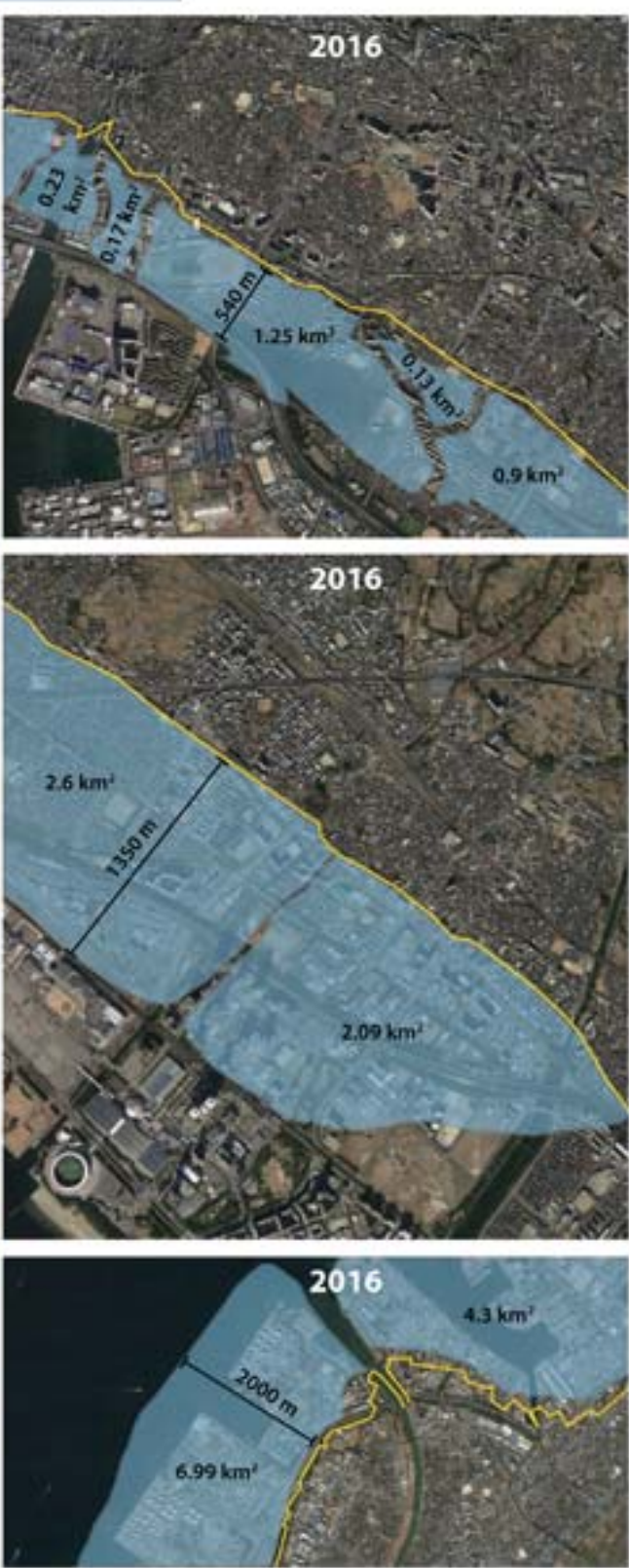

Figure 7. Disappearance of Tokyo bay mudflats under land reclamations, where the coastline has been artificially built out seaward by $>1 \mathrm{~km}$ over the last century. The shoreline has progressed over the sea, increasing the water depth at the shoreline, while at the same time an increasing number of river-work and dams have significantly reduced the amount of sediment outputs in rivers. 
They have been replaced by hard shores in the form of concrete walls and blocks rising $>5 \mathrm{~m}$ above sea level. Such shoreline elevations are paralleled elsewhere in Tokyo bay only by Pleistocene age sediment deposits, with post-Pleistocene sedimentation being less consolidated and lower in elevation than the present-day reclaimed shores (Figure 6-B). Given these comparisons, one might expect that land reclamation around Tokyo's coastlines will have long-lasting effects on erosion and sedimentation conditions.

In addition to anthropogenic land reclamation and shoreline hardening, human modification of coastal cliff erosion processes can also have lasting effects on future shoreline stability and deposit dynamics. In Christchurch, in the aftermath of the CES, multiple, large slips, rockfalls and other mass movement events occurred around the coastal cliff fringes of northern Banks Peninsula, including in the suburbs of Sumner (with 'Scarborough' shoreline bordering the southeastern part of the suburb), Redcliffs and also in Lyttelton Harbour. Where the new talus and rockfall debris interfered with infrastructure use or caused safety concerns, it was removed (Figure 8). The excavation included removing both natural and anthropogenic debris from the cliff bases, faces and tops. Although a large part of the material will remain on site, considerable volumes were shifted and transformed. The consented work includes the removal of $63,000 \mathrm{~m}^{3}$ of material $\left(\sim 53,000 \mathrm{~m}^{3}\right.$ of soil and $10,000 \mathrm{~m}^{3}$ of rocks) and the removal of unstable rocks from the cliff side (Christchurch City Council, 2016). Such removal of fallen material can have long lasting effects on the future evolution of the landscape (Figure 9). The removal of the fallen debris at the bottom of a cliff can have an analogous effect to the hard-engineering used in land reclamation, where a buffer against erosion processes is removed, accelerating erosion rates. In the case of Tokyo's land reclamation, mudflat removed allowed more direct wave attack at the shore whereas in the case of Sumner, the removal of talus means less support and protection from subaerial weathering at the cliff face under present conditions. In this future, with accelerated SLR, it could also mean more direct interaction between the sea and cliffs. For most of the suburb of Sumner, including the area called Scarborough, seawalls and riprap revetments separate the sea and hinterland, including some low lying Holocene valley fill deposits and cliffs. The contact between the sea and hardened shorelines has also changed the sediment dynamics of this coast, accelerating beach erosion in places (Carter, 2007).

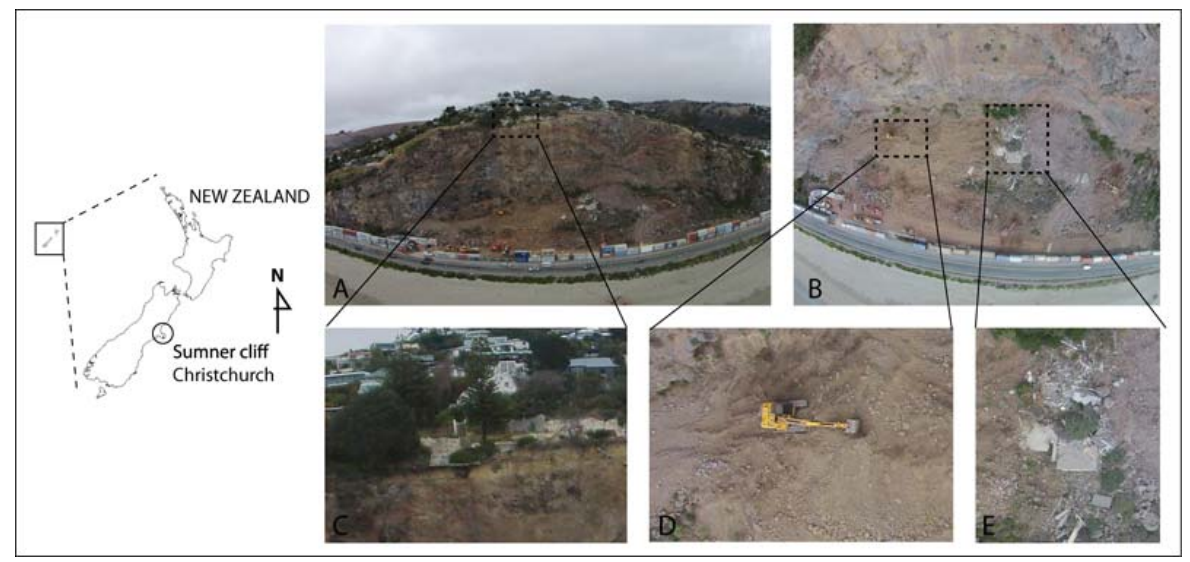

Figure 8. Excavation site in Sumner, Christchurch New Zealand, following the February 2011 Earthquake sequence. (A) Side view of the excavation site; (B) Plan view of the excavation site; (C) Zoom on the 'blue-edge' properties; (D) and $(E)$ zooms on the excavator and a collapsed concrete house. 


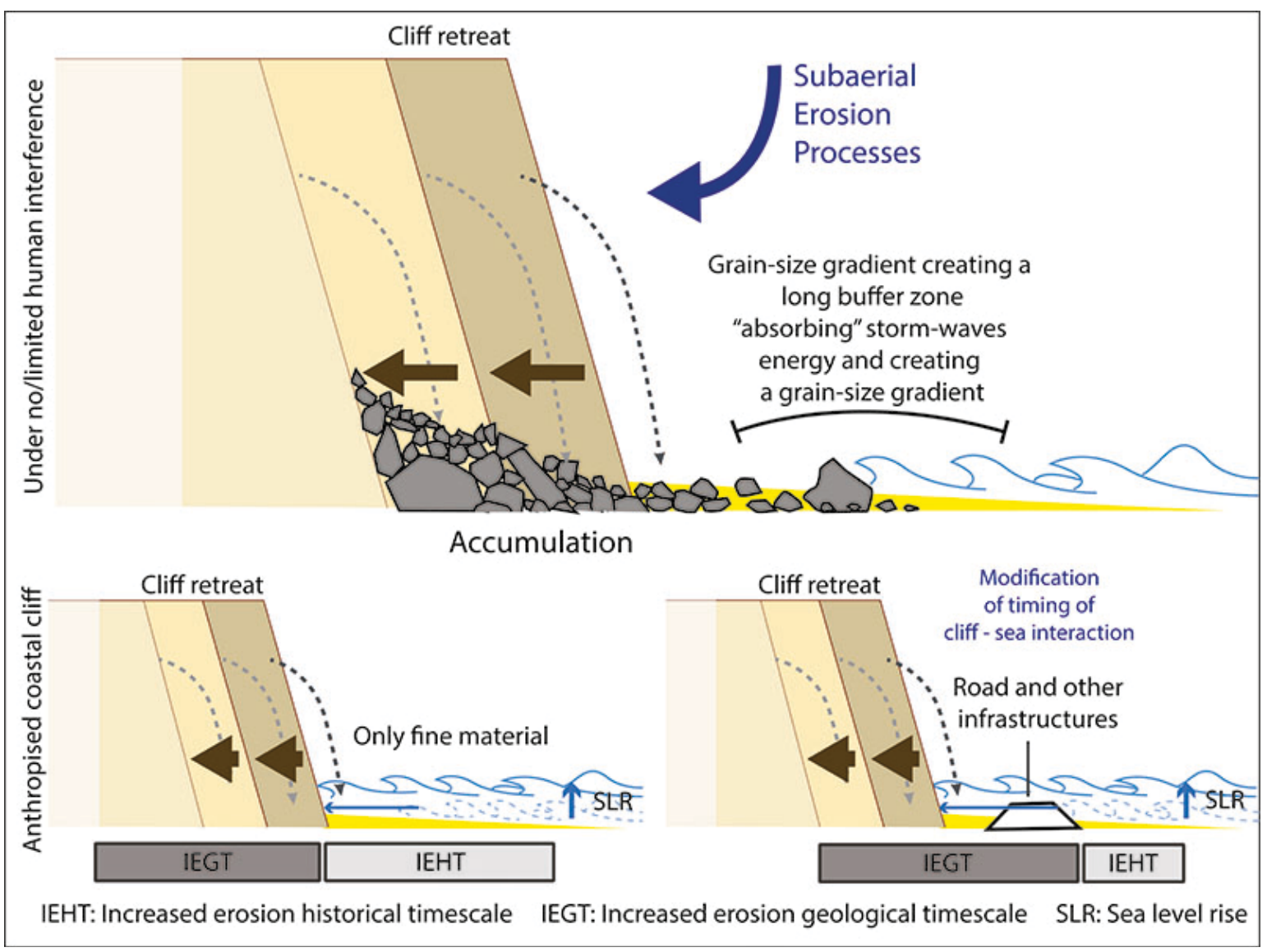

Figure 9. Conceptual model showing how anthropogenic sediment excavation can increase rates of coastal cliff erosion over the long-term, as the cliff eroded by subaerial processes do not keep their aprons, by then also modifying the sedimentary gradient towards the sea. There may be even greater potential for erosion where anthropogenic acceleration of SLR enhances cliff-sea contact.

3.3. Tsunamis in the AnthropoceneEvidence from the 2004 Indian Ocean Tsunami and the 2011 Tohoku tsunami. Compared to the above examples, the imprint of anthropogenic activity on surface processes and sediment deposits is even clearer when investigating extreme events such as tsunamis. Indeed, in their passage through nearshore and terrestrial environments, tsunamis interact with anthropogenic infrastructure, both in terms of their hydrodynamic behaviour and also in terms of the sediments they can access, transport and deposit.

In Sumatra, in the aftermath of the 2004 Indian Ocean Tsunami, UN reconnaissance flights provided insights into the extent and distribution of resulting damage. At the same time, this record revealed the extensive role played by horizontal infrastructure (or lifelines) in shaping tsunami effects (Figure 10). For example, the coastal plain is largely flat and occupied by paddy fields, with the only significant interruption to this very tsunami-conductive surface being the elevated asphalt roads, which effectively blocked low-energy tsunami inundation in many areas (Figure 10). The roads also interacted with the tsunami waves to produce strong eddy currents, accentuating erosion and creating scour holes (Figure 10). Similarly dynamic effects were observed in the lee of concrete buildings, which blocked the tsunami flow path, resulting in scour depressions as the waves wrapped around the structures. 


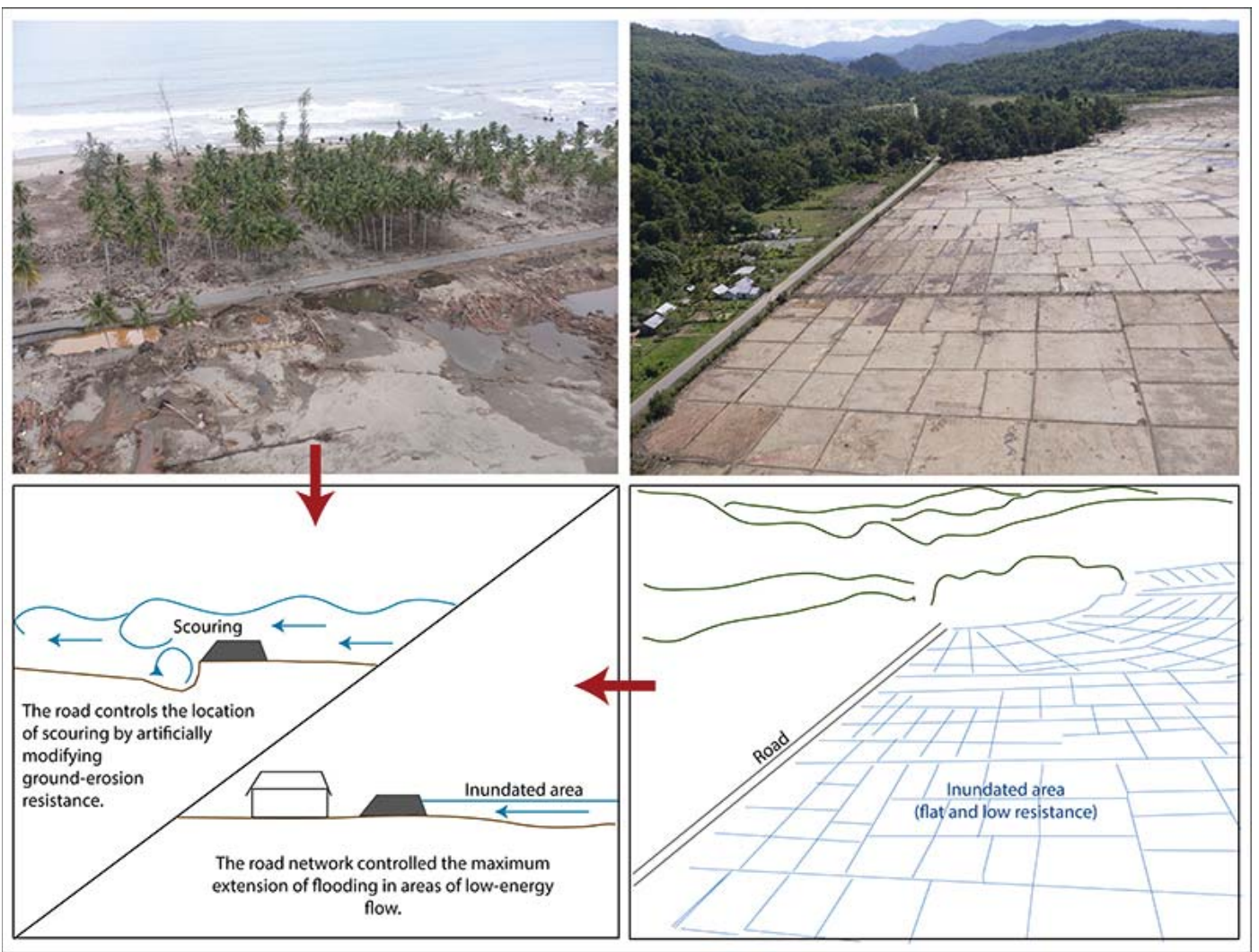

Figure 10. The role of road networks in controlling tsunami inundation, scour and sedimentation patterns (photographs by Wassmer).

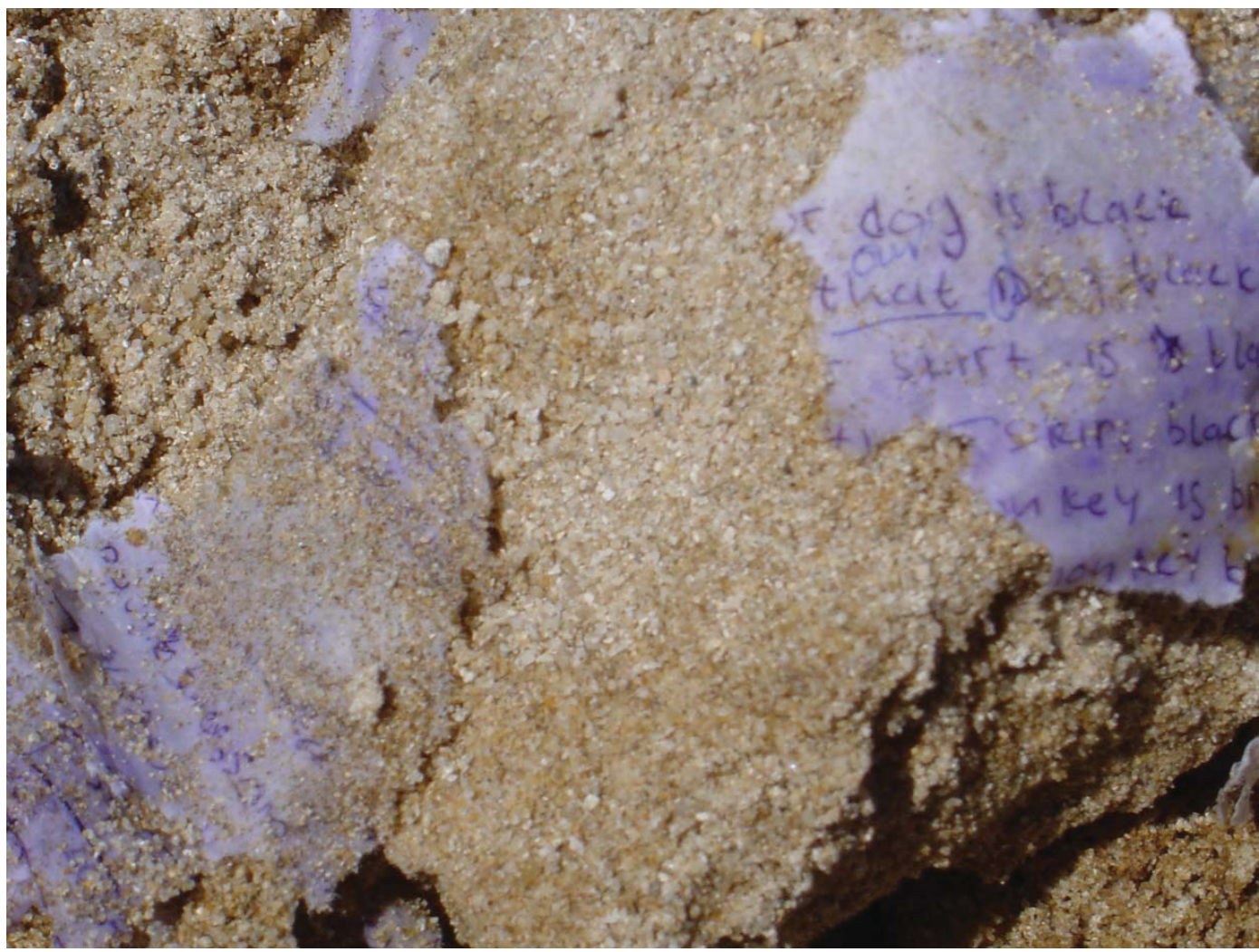

Figure 11. Sample of anthropogenic material found in tsunami deposits in the aftermath of the 2004 Indian Ocean Tsunami in North Sumatra. The backwash wave captured the most anthropogenic material, making its deposits easily distinguishable from uprush wave deposits, which carried materials of marine origin only (photo: courtesy of Lavigne). 
In the sedimentary record of the tsunami, one of the most striking evidence of backwash was the conservation of anthropogenic material (bricks, bottles...) in the sediment units. More unusual debris were also found, like torn apart children notebooks (Figure 11). Similarly, in the
Tohoku area the authors dug several pits, along waterways, landward of shoreline protection structures, and in unconsolidated shores, to investigate the tsunami deposits. Most of the areas exhibited broken pieces of anthropogenic material (Figure $12 \mathrm{C}$ and D).
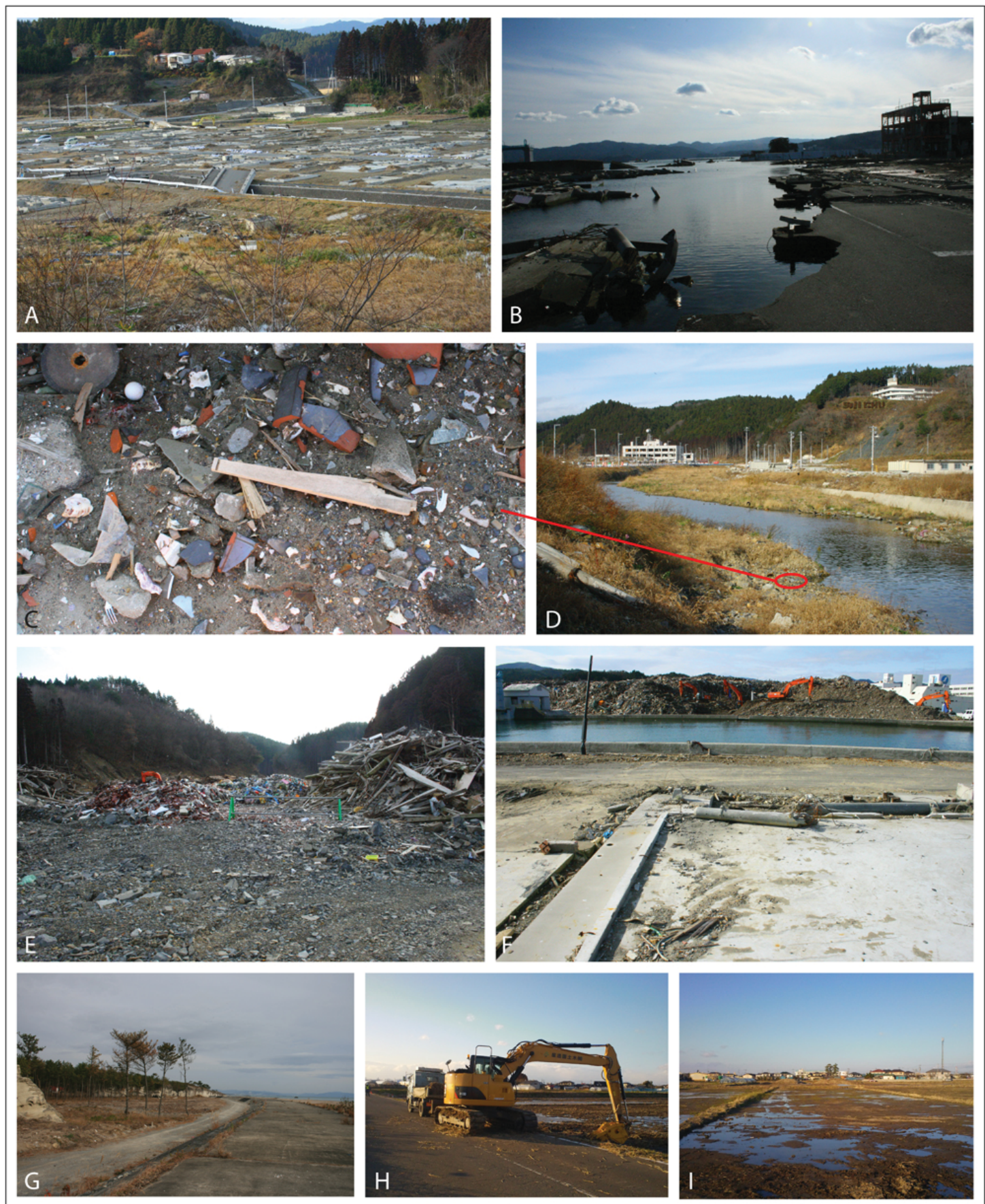

Figure 12. The Tohoku tsunami in 2011 (Japan) and its interaction with anthropogenic environments: (A) House slabs and collapsed bridge in Kesennuma; (B) The eroded and undermined Minami-Sanriku port area infrastructure; (C and D) Tsunami backwash deposits in a Minami-Sanriku riverbed; (E) Material near Motoyoshi in a valley near the trainline; (F) Debris being gathered and transported away in Minami-Sanriku: (G) Coastline in Higashi-Matushima; $(H)$ Excavation of sandy sediments from Sendai plain rice fields; (I) Excavated Sendai rice field. 


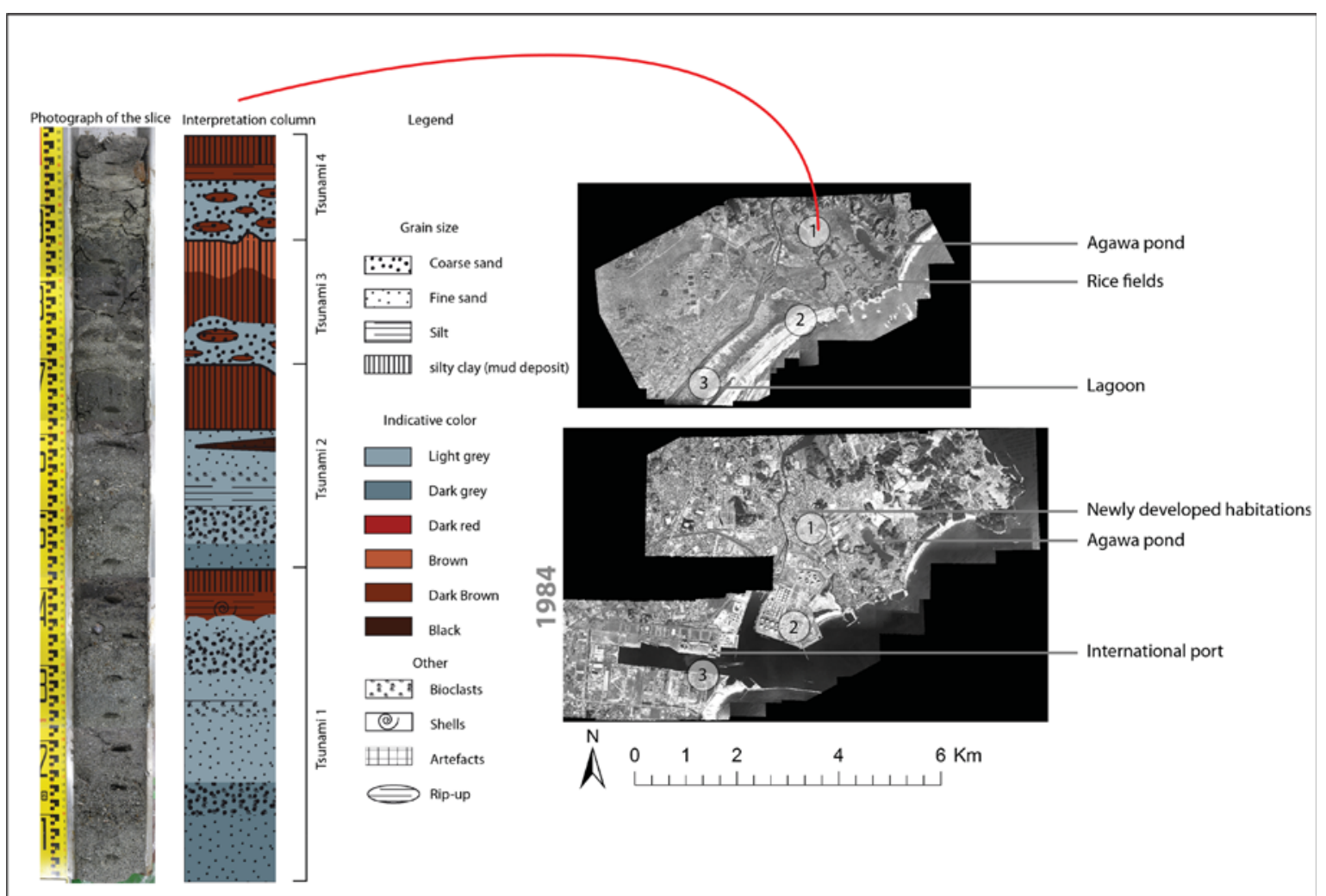

Figure 13. Successive tsunami deposits (left) recorded in Agawa pond (1), and aerial photograph records of northern Sendai plain, Japan (right) from 1947 and 2006, showing the transformation of an unconsolidated sandy coastline into concrete harbour structures (2 and 3). Note the plastic material trapped at the very top of the sediment core column (left) - another example of anthropogenic material integrated into the sediment record.

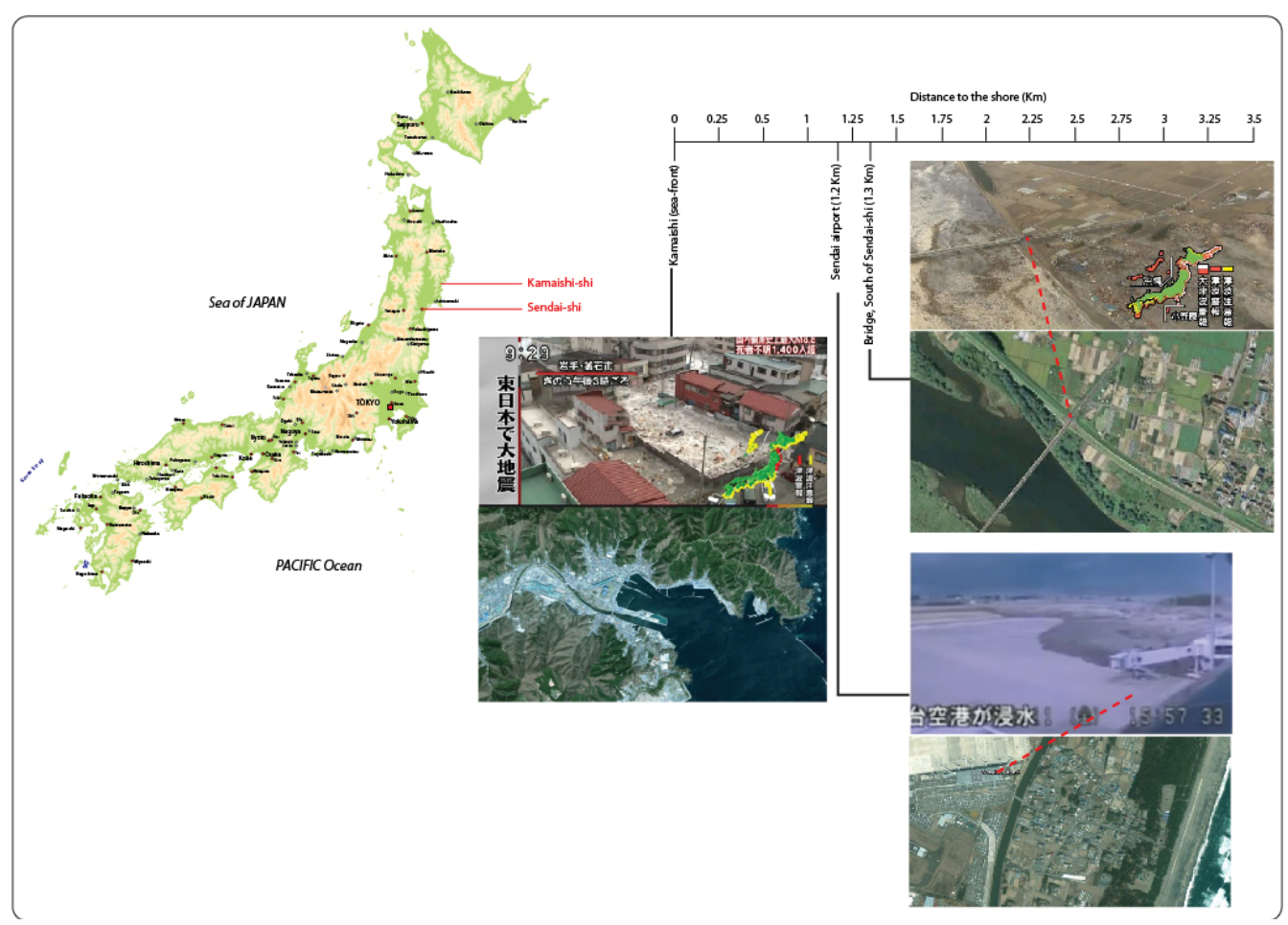

Figure 14. Sediment transport and the role of infrastructure in modifying tsunami flow (including changing the flow from Newtonian to 'debris flow') as revealed by pre- and post-tsunami aerial images of the Sendai and Karmaishi areas (the image of the airport is the third one in the right column). 
Ourobservationsrevealthatanthropogenic activity can also have another, very different effect on tsunami sediment deposits - that of reducing the records left behind (Figure $12 \mathrm{E}$ to I). In the aftermath of the 2011 tsunami in Japan, large amounts of debris were excavated and collected for burying away from their tsunami deposition site around different parts of Japan - this included the construction of artificial islands in Hiroshima bay - rendering some tsunami deposit covered areas eventually bare. On Sendai plain (Figure $12 \mathrm{H}$ and I), between the Sendai city highway and the sea, paddy fields were cleaned of debris as well as of all sand deposits and soil layers that might have been contaminated with sea-water in order to rehabilitate the area's rice production capability. Unfortunately, this procedure also eliminated from the sedimentary record any trace of the tsunami deposit across huge tracts of land. This is not a new phenomenon in Japan. Although not widely known, research literature indicates that numerous parts of Japan, including Sendai plain, have experienced the importation and distribution of what is known as 'kyaku-dou' or the 'guest soil', which is material that has been transferred across the isles of Japan as early as the $16^{\text {th }}$ and $17^{\text {th }}$ century A. D. This guest soil makes the reconstruction of past tsunami events from sedimentary records very difficult in many parts of the country.

Urbanisation has also affected the character of Japan's tsunami deposits. In Agawa pond, towards the northern end of Sendai plain, the record of past tsunami exhibits a progressive thinning of sedimentary records from tsunami events (Figure 13). Despite the 2011 Tohoku tsunami being the largest such event in the region since the Jogan tsunami (around 800 $\mathrm{AD})$, its deposits represent one of the thinnest layers in the pond above the last soil or lake bed deposit. This progressive thinning of tsunami deposits correlates with increasing levels of anthropogenic development of the coast here, which has produced a diminution in the sediment sources available to tsunami waves for deposition. For example, in 1947, the locations 2 and 3 illustrated in Figure 13 comprised unconsolidated beach sands, but by 1984 these deposits had been replaced by several minor concrete port structures and one major dredged port structure (3). The correlation between extensive shoreline hardening and development and a paucity of sediment available for transport by tsunami waves is supported by visual evidence from videos showing the 2011 tsunami inundation of the Tohoku area. For example, the tsunami inundation waters that swept across coastal bay villages, where shoreline and nearshore development is typically advanced, were relatively clean and free from heavy sediment loads. In contrast, where the tsunami waves traversed less urbanised areas of the open coast, such as by Sendai plain, the inundation waters rapidly became debris-rich, with debris-laden flows apparent near the airport (Figure 14).

\subsection{Discussion}

Evidence from three island nations, New Zealand, Japan and Indonesia, indicates that anthropogenic forcing is currently an important influence in both sedimentologically unconsolidated (e.g. Tokyo mudflats, and Tohoku and Sumner sand beaches, in Japan and New Zealand) and rocky coastal environments (e.g. Sumner in New Zealand). This evidence also reveals how everyday interactions between anthropogenic and geomorphic processes can alter the response of coastal systems to low-frequency, high-energy events such as tsunamis (e.g. the modified sediment deposits of Tohoku available for wave transport, plus the built infrastructure of Tohoku and Indonesia influencing wave hydrodynamics and geomorphic scour) and earthquakes (e.g. the anthropogenic clearance of mass movement debris from highly developed coastal suburbs in Christchurch, as well as cascading effects on the flood susceptibility of the city's coastal plain). This includes the high-energy events interacting with built infrastructure, and being modified (e.g. hydrodynamic and sediment processes) by human activity on the coast, as well as the influence of anthropogenic activity as recorded in sediment deposits. 
The present contribution has therefore evidenced that: (1) anthropogenic constructs modify flows and waves of water and sediments at the coast (river flows, coastal sedimentation as well as rarer events like tsunamis overland flows); (2) anthropogenic constructs also modify the ratio of sediments per volume of water during flows and waves (tsunamis); (3) anthropogenic climate change will modify the river gradients and thus modify the hydrology and the sediment distribution in coastal areas (even if the sea-component is unresolved); (4) Over long term, points 1, 2 and 3 implies change in the sediment records of similar events; (5) sediment records are and will include anthropogenic debris.

The coastal environment snapshots examined in this study have been limited in time and space to specific locals and sets of processes, and also to a narrow 'field of view' of geomorphology focussing on physical processes and sedimentary records. However, it is important to consider these snapshots alongside the additional influences on coasts of anthropogenic activity upstream in catchment environments, as well as the influence that humans have had on coastal geomorphology through their role as a biological agent of change (Marsden et al., 2016). Along the Sacramento River in California, for example, the Shasta dam prevents the in-stream transport of coarser sediments (gravels), only allowing only the entrainment and transport of finer grained sediments (pebbles and sands), even during the controlled flood flow releases. It consequently influences the floodplain construction and the sediment record of the geomorphological features (Gomez et al., 2010) while modifying the material transported to the coast. Downstream impacts of anthropogenic constructs in land-catchments do not always have immediate effects on the coastal systems however. If one consider rivers as conveyerbelt from the mountain to the coast, those conveyer belt can be either disrupted by the construction of dams and various steps, either reducing their energy or stocking the material along the way, or the construction can limit the amount of material brought to the conveyer belt, like urbanisation or stopbanks, which "fix" the landscape and reduce the amount of fine sediments carried to the conveyer belt - especially during exceptional events. Engineers have however tried to respond to those changes by introducing sediments in the system. Even in rivers like the Sacramento River, where changes have been observed (Gomez et al., 2010), large amount of sediments were introduced to counteract the effects of dams (Denton, 1991; Kondolf and Matthew, 1993).

The manifestation of the anthropogenic effects is also dependent of the time and space scales as well as the rhythms of the landscape. Indeed, although the coupling of human and "natural" affect is undeniable (Werner and McNamara, 2007), the above mentioned disruptions will have very different effects depending on where they are located. As known denudation rates in mountain environment can vary by a factor of a thousand, even within the "temperate zone" - with values of $0.01 \mathrm{~mm} / \mathrm{yr}$ in the Northern American Apalachian range (Leopold et al., 1964) to an estimated $11 \mathrm{~mm} /$ yr in the Alps of New Zealand (Griffith and McSaveney, 1983) - the rate of disruption by a human construct would have very different impacts. The downstream consequences therefore vary in time and scale (Kondolf and Podolak, 2014).

At the coast and from one of our case study sites - Christchurch - humans have removed, reconstructed and reshaped, and limited the development of dunes via their manipulation of dune vegetation species (Hart and Knight, 2009). At yet another of our case study sites, the removal of saltmarsh in Tokyo has undoubtedly had significant effects on the hydrology and surface stability of remaining intertidal deposits (e.g. Liénard et al., 2016), not to mention the loss of biological diversity, productivity and ecosystems services that have occurred. Those modifications will also have impacts during more punctual events, like 
tsunami. As coastal dunes have been eroded by the tsunami in Lampuuk (South of Banda Aceh) in 2004 (Kain et al., 2014), they have acted as a buffer dissipating the energy of the tsunami. Consequently coconut tree plantations located at the back of those sand dunes were left relatively undisturbed, if not for the sand from the dunes being deposited in a thick layer in between the coconut stems (Gomez et al., 2008). Once again, the consequences of anthropogenic modification on the geomorphic processes and the recording of their sediment structure might not be immediately apparent and therefore difficult to assess within solely the human lifespan.

Consequently, when one thinks about the coastal system as an anthropogenic system, or as the coast in the Anthropocene, one does not mean that the coast solely has been impacted, but rather that the Earth and environmental system within which the coast is located has been modified to the point that present and future responses of the coast is and will be controlled by broader anthropogenic forcing.

\section{Conclusion}

Human activity has already modified the sedimentary records in coastal areas, and will continue to do so as it has also changed the very processes that generate those deposits. Moreover, it is not only the characteristics of the sedimentary deposit or its emplacement, erosion that is affected, it is what it contains: human artefacts are now an integrant part of the sedimentary records. In the present contribution, we put the emphasis on the subaerial and terrestrial parts of the coastal system, where anthropogenic impacts have been clearly identified, but it is certain that changes in the sea environment (e.g. modification of shore currents, increased typhoons and associated sea-conditions, anthropogenic climate change) also impacts coastal areas.

\section{Acknowledgment}

The authors are grateful to two anonymous reviewers and the editorial board for the careful handling.

\section{References}

Allen, J., Davis, C., Giovinazzi, S., Hart, D. E., Cochrane, T., Deam, B., ... \& Johnson, L. (2014). Geotechnical \& flooding reconnaissance of the 2014 March flood event post 2010-2011 Canterbury earthquake sequence, New Zealand. Report No. GEER035.

Benedet, L., List, J.H. (2008) Evaluation of the physical process controlling beach changes adjacent to nearshore dredge pits. Coastal Engineering Vol. 55, pp. 1224-1236.

Blum, M. D., Roberts, H.H. (2009) Drowning of the Mississippi Delta due to insufficient sediment supply and global sea-level rise. Nature Geosciences 2, pp. 488-491.

Butler, D. R. (1995) Zoogeomorphology: animals as geomorphic agents. Cambridge University Press.

Butler, D. R., Sawyer, C. F. (2012) Introduction to the special issue - zoogeomorphology and ecosystem engineering. Geomorphology Vol. 157, pp. 1-5.

Canterbury Geotechnical Database. (2014) Event Specific Groundwater Surface Elevations, Map Layer CGD0800 - 12 June 2014, retrieved from https://canterburygeotechnicaldatabase. projectorbit.com/

Canterbury Geotechnical Database. (2012a) LiDAR and Digital Elevation Models, Map Layer CGD0500 - 23 July 2012, retrieved from https://canterburygeotechnicaldatabase. projectorbit.com/

Canterbury Geotechnical Database. (2012b) Vertical Ground Surface Movements, Map Layer CGD0600 - 23 July 2012, retrieved from https://canterburygeotechnicaldatabase. projectorbit.com/ 
Carter, J. (2007) Changes in the Sumner coastline, Pegasus Bay: A Study of Beach variation from 1940 to 2007. Honours Dissertation (Geography), University of Canterbury, available from: http:// www.geog.canterbury.ac.nz/postgrad/420s.shtml

Christchurch City Council. (2016) Report/Decision on Non-notified Resrouce Consent Application RMA92032581 - Land remediation applications to be processed non-notified, Deans Head. http:/ /ccc.govt.nz/assets/Documents/The-Council/HYS/2016/april/RMA92032581Decision-Deans-Head-Land-Remediation-and-Shag-Rock-Infilling.pdf.PDF (retrieved September 30, 2016).

Crutzen, P. J. Stoermer, E.F. (2000) The 'Anthropocene'. Global Change Newsletter Vol. 41, pp. 1718.

Denton, D. N. (1991) Sacramento River gravel restoration progress report. California Department of Water Resources, Ref Bluff, California, January 1991.

Davis, C. A., Giovinazzi, S. Hart, D.E. (2015) Liquefaction Induced Flooding in Christchurch, New Zealand. Proceedings of the 6th International Conference on Earthquake Geotechnical Engineering (6ICEGE), 1-4 Nov 2015, Christchurch, New Zealand, 6p.

Gomez, C., Lavigne, F. Lespinasse, N. (2008) New insights of geomorphologic impacts of the December 2004 tsunami through GPR investigation. In Lavigne, F., Paris, R., Hadmoko, D.S. (Eds.). The 2004 Tsunami in North Sumatra, EFEO Jakarta, 300pp.

Gomez, C., Piegay, H. Fremier, A. (2010) Floodplain polygenesis: from Geomorphic construction to Forest patterns. San Francisco, CA, USA: American Geophysical Union 2010 Fall Meeting, 13-19 Dec. 2010.

Gomez, C., Soltanzadeh, I. (2012) Boundary crossing and non-linear theory in earth-system sciences: A proof of concept based on tsunami and post-eruption scenarios on Java Island, Indonesia. Earth Surface Processes and Landforms Vol. 37, pp. 790-796.

Griffiths, G. A., McSaveney, M. J. (1983) Hydrology of a basin with extreme rainfalls - Cropp River, New Zealand. New Zealand Journal of Science Vol. 26, pp. 293-306.

Hall, K., Lamont, N. (2003) Zoogeomorphology in the Alpine: some observations on abioticbiotic interactions. Geomorphology Vol. 55(1), pp. 219-234.

Hannah, J., Bell, R.G. (2012) Regional sea level trends in New Zealand. Journal of Geophysical Research: Oceans 117(C1).

Hart, D.E. (2014) What if Christchurch's sea levels continue to rise. University of Canterbury 'What if?' public seminar series talk. Available from: https://www.youtube.com/ watch? $=9$ ihXuBFIjQk

Hart, D. E., Byun, D-S. Giovinazzi, S. Hughes, M.W. Gomez, C. (2015) Relative Sea Level Changes on a Seismically Active Urban Coast: Observations from Laboratory Christchurch. Proceedings of the Australasian Coasts \& Ports Conference 15-18 Sep 2015, Auckland, New Zealand, 6p.

Hart, D. E., Gomez, C. (2013) Coastal Quakes: Observations and analyses from backyard Christchurch to 21st century coastal megacities. Coastal News Vol. 54, pp. 1-3.

Hart, D. E., Kench, P.S. (2007) Carbonate production of an emergent reef platform, Warraber Island, Torres Strait, Australia. Coral Reefs Vol. 26(1), pp. 53-68.

Hart, D. E., Knight, G.A. (2009) Geographic information system assessment of tsunami vulnerability on a dune coast. Journal of Coastal Research Vol. 25(1), pp. 131-141.

Hooke, J. M., (2007) Complexity, self-organisation and variation in behavior in meandering rivers. 
Geomorphology Vol. 91, pp. 236-258.

Houben, P., Smith, M. Mautz, B. Strobbe, A. Lang, A. (2012) Asynchronous Holocene colluvial and alluvial aggradation: a matter of hydrosedimentary connectivity. The Holocene Vol. 23, pp. 544-555.

Hudson, B. J. (1980) Anthropogenic Coasts. Geography Vol. 65, pp. 194-202.

Kain, L. C., Gomez, C. Wassmer, P. Hard. D.E. (2014) Truncated dunes as evidence of the 2004 tsunami in North Sumatra and environmental recovery post-tsunami. New Zealand Geographer Vol. 70, pp. 165-178.

Knight, J., Harrison, S. (2013) The impacts of climate change on terrestrial Earth Surface Systems. Nature Climate Change Vol. 3, pp. 24-29.

Kondolf, G. M., Matthews, W.V.G. (1993) Management of coarse sediment in regulated rivers of California, Universiy of California, Davis, Water Resources Center Report 80.

Kondolf, G. M., Podolak, K. (2014) Space and Time Scales in Human-Landscape Systems. Environmental Management Vol. 53, pp. 76-87.

Kowalinski, S., Pons, L.J. Slager, S. (1972) Micromorphological compareson of three soils derived from loess in different climatic regions. Geoderma Vol. 7, pp. 141-158.

Leopold, L. B., Wolman, M.G. Miller, J.P. (1964) Fluvial processes in geomorphology. San Francisco, 522pp.

Liénard, J., Lynn K., Strigul, N. Norris, B.K. Gatziolis, D. Mullarney, J.C. Bryan, K.R. Henderson, S.M. (2016) Efficient three-dimensional reconstruction of aquatic vegetation geometry: Estimating morphological parameters influencing hydrodynamic drag. Estuarine, Coastal and Shelf Science Vol. 178, pp. 77-85.

Lotze, H. K., Lenihan, H.S., Bourque, B.J., Bradbury, R.H., Cooke, R.G., Kay, M.C., Kidwell, S.M., Kirby, M.X., Peterson, C.H., Jackson, J.B. (2006) Depletion, degradation, and recovery potential of estuaries and coastal seas. Science Vol. 312(5781), pp. 1806-1809.

Marsden, I. D., Hart, D.E. Reid, C.M. Gomez, C. (2016) Earthquake disturbances. In: M.J. Kennish (Ed.), Encyclopedia of Estuaries: pp. 207-214. Dordrecht: Springer.

Masselink, G. Gehrels, W.R. (2014) Coastal environments and global change (1 ${ }^{\text {st }}$ ed.). Hoboken, NJ: Wiley.

Ozesmi, S. L., Bauer, M.E. (2002) Satellite remote sensing of wetlands. Wetlands Ecology and Management Vol. 10(5), pp. 381-402. doi:10.1023/ A:1020908432489

Parkinson, C. L. DiGirolamo, N. E. (2016) New visualizations highlight new information on the contrasting Arctic and Antarctic sea-ice trends since the late 1970s. Remote Sensing of Environment Vol. 183, pp. 198-204.

Phillips, J. D., (2009) Changes, perturbations and responses in geomorphic systems. Progress in Physical Geography Vol. 33, pp. 17-30.

Pitlick, J., Wilcock, P. (2001) Relations between streamflow, sediment transport and aquatic habitat in regular rivers. Geomorphic Processes and Riverine Habitat, Water Sciences and Applications Vol. 4, pp. 185-198.

Qu, J. J., Powell, A.M. Siva Kumar, M.V.K. (2013) Satellite-based applications on climate change. Dordrecht, London: Springer.

Rodriguez-Ramirez, A., Morales, J.A. Delgado, I. Cantano, M. (2008) Impact of man on the 
morphodynamics of the Huelva coast (SW Spain). Journal of Iberian Geology Vol. 34, pp. 313327.

Rull, V. (2016) The Humanized Earth System (HES). The Holocene Vol. 26, pp. 1513-1516.

Shakesby, R. A., Doerr, S.H. (2006) Wildfire as a hydrological and geomorphological agent. Earth Science Review Vol. 74, pp. 269-307.

Stanley, D. J., Warne, A.G. (1993) Nile Delta: recent geological evolution and human impact. Science Vol. 260, pp. 628-628.

Stoppani, A. (1873) Corso di Geologica. Milano. G. Bernardoni \& E.G. Brigola (Eds.).

Syvitski, J. P. M., Saito, Y. (2007) Morphodynamics of deltas under the influence of humans. Global and Plantetary Change Vol. 57, pp. 61-78.

Tarolli, P., Sofia, G. (2016) Human topographic signatures and derived geomorphic processes across landscapes. Geomorphology Vol. 255, pp. 140-161.

Trischler, H. (2016) The Anthropocene. NTM Zeitschrift für Geschichte der Wissenschaften, Technik und Medizin, 1-27. doi:10.1007/s00048-016-0146-3.

Tsai, H. M., Clark, E. (2003) Nature Society Interactions on Islands: Introduction. Geografiska Annaler: Series B, Human Geography Vol. 85(4), pp. 187-189.

van Maanen, B., Coco, G. Bryan, K.R. (2015) On the ecogeomorphological feedbacks that control tidal channel network evolution in a sandy mangrove setting. Proceedings of the Royal Society A: Mathematical, Physical and Engineering Science Vol. 471(2180), 20150115.

Walling, D. E. (2006) Human impact on land-ocean sediment transfer by the world's oceans. Geomorphology Vol. 79, pp. 192-216.

Wang, Q., Jorgensen, S. E., Lu, J.J. Nielsen, S.N., Zhang, J.R. (2013) A model of vegetation dynamics of Spartina alterniflora and Phragmites australis in an expanding estuarine wetland: Biological interactions and sedimentary effects. Ecological Modeling Vol. 250, pp. 195-204.

Wassmer, P., Gomez, C. (2011) Development of the AMS Method for Unconsolidated Sediments, Application to Tsunami deposits, Geomorphologie: Releif Processus et Environnement Vol. 3, pp. 279-290.

Wassmer, P., Gomez, C., Iskandasyaht, T., Lavigne, F., Sartohadi, J. (2015) Contribution of Anisotropy of Magnetic Susceptibility (AMS) to reconstruct flooding characteristics of a $4220 \mathrm{BP}$ tsunami from a thick unconsolidated structureless deposit (Banda Aceh, Sumatra). Frontiers in Earth Science Vol. 3, 40, doi:10.3889/feart.2015.00040.

Waters, C. N., Zalasiewicz, J., Summerhayes, C., Barnosky, A. D., Poirier, C., Gałuszka, A., Cearreta, A., Edgeworth, M., Ellis, E. C. (2016) The Anthropocene is functionally and stratigraphically distinct from the Holocene. Science Vol. 351(6269): aad2622. doi:10.1126/ science.aad2622.

Wei, W., Mei, X., FDai, Z., Tang, Z. (2016) Recent morphodynamic evolution of the largest uninhibited island in the Yangtze (Changjiang) estuary during 1998-2014: influence of the anthropogenic interference. Continental Shelf Research Vol. 124, pp. 83-94.

Werner, B. T., McNamara, D. E. (2007) Dynamics of coupled human-landscape systems. Geomorphology Vol. 91, pp. 393-407.

Wilkinson, B. H. (2005) Humans as geologic agents: a deep-time perspective. Geology Vol. 33-161.

Wohl, E. (2013) Wilderness is dead: whither critical zone studies and geomorphology in the 
Anthropocene? Anthropocene Vol. 2, pp. 4-15.

Wolf, D. Seim, A. Faust, D. (2014) Fluvial system response to external forcing and human impact - Late Pleistocene and Holocene fluvial dynamics of the lower Guadalete River in western Andalucia (Spain). Boreas Vol. 43, pp. 422-449.

Woodroffe, C. D., Samosorn, B. Hua, Q. Hart, D.E. (2007) Incremental accretion of a sandy reef island over the past 3000 years indicated by component specific radiocarbon dating. Geophysical Research Letters Vol. 34(3), doi 10.1029/2006GL028875. 